\title{
Access to effective refugee protection in South Africa: legislative commitment, policy realities, judicial rectifications?
}

\author{
Article
}

Published Version

Creative Commons: Attribution 4.0 (CC-BY)

Open Access

Ziegler, R. (2020) Access to effective refugee protection in South Africa: legislative commitment, policy realities, judicial rectifications? Constitutional Court Review, 10. pp. 65-106. ISSN 2073-6215 doi: https://doi.org/10.2989/CCR.2020.0004 Available at https://centaur.reading.ac.uk/90702/

It is advisable to refer to the publisher's version if you intend to cite from the work. See Guidance on citing.

To link to this article DOI: http://dx.doi.org/10.2989/CCR.2020.0004

Publisher: Juta Law

All outputs in CentAUR are protected by Intellectual Property Rights law, including copyright law. Copyright and IPR is retained by the creators or other copyright holders. Terms and conditions for use of this material are defined in the End User Agreement.

\section{$\underline{\text { www.reading.ac.uk/centaur }}$}

\section{CentAUR}


Central Archive at the University of Reading

Reading's research outputs online 


\title{
Access to Effective Refugee Protection in South Africa: Legislative Commitment, Policy Realities, Judicial Rectifications?
}

\author{
RUVI ZIEGLER
}

\begin{abstract}
Just over two decades ago, South Africa (SA) adopted the Refugees Act 130 of 1998 (RA), which incorporated the Republic's global and regional international refugee law (IRL) obligations. For its time, the RA was progressive and advanced in terms of the scope and content of protection it provided for refugees. The coming into force on 1 January 2020 of the Refugees Amendment Act 11 of 2017 (RAA 2017) substantively and detrimentally altered SA's refugee protection landscape by severely restricting access to the asylum regime and by denying asylum-seekers substantive rights that were previously available to them. The amended RAA 2017 also withdrew status and protection from refugees, recognised as such under IRL. Indeed, many new provisions now arguably violate both SA's international obligations and its Constitution.
\end{abstract}

Two decades after the coming into effect of the RA, this article critically appraises access to effective refugee protection in SA through an international refugee law lens. It argues that SA courts were forced to straddle between the legislative promise of the RA and Executive policies designed to limit access to asylum procedures and to deny asylum-seekers substantive rights. Courts have extended constitutional protection to those physically in the Republic, irrespective of their legal status in SA. They have utilised the principle of nonrefoulement, enumerated in $\mathrm{s} 2$ of the RA, to bridge a protection gap between 'asylum-seeker' (per the RA) and 'illegal foreigner' (per the Immigration Act 13 of 2002), ensuring access to the asylum process by requiring the issuance or renewal of asylum permits. Courts have also utilised the constitutional right to dignity to facilitate asylum-seekers' (partial) access to substantive rights to employment, to basic medical care, to education, and to marry South Africans, which the Executive (through directives, regulations, and other policies) sought to deny them. Yet, generally, in their asylum jurisprudence, SA courts have not utilised IRL, let alone as the primary interpretive source, and they have refrained from pronouncing on policies' incompatibility with the Republic's international obligations in the light of the declaratory nature of refugee status.

The adverse effects of the RAA 2017 render inevitable its constitutional review. This article argues that, 'armed' with the much-strengthened interpretive role of IRL \& International Human Rights Law (as mandated by the Refugees Amendment Act 33 of 2008), SA courts must be prepared to declare certain RAA 2017 provisions (and their accompanying Regulations) as unconstitutional. 
KEYWORDS: 1951 Convention, Bill of Rights, detention, employment, International Refugee Law, nonrefoulement, Refugees Act, Refugees Amendment Act 2017, political activities

AUTHOR: Associate Professor in International Refugee Law, University of Reading, UK; Visiting Professor, Faculty of Law, University of Johannesburg, South Africa Email: r.ziegler@reading.ac.uk

ACKNOWLEDGEMENTS: I am indebted to Hennie Strydom for hosting me as a visiting professor at the South African Research Chair in International Law, University of Johannesburg. I am also grateful for the support I received from the Research Activities Fund of the Society of Legal Scholars (UK). Thanks are due to Einat Albin, Jason Brickhill, Tomer Broude, David Cantor, James Green, Fatima Khan, Nicholas Maple, Chris McConnachie, Stephen Meili, Sarah-Jane Savage, the journal editors, and two anonymous reviewers for very helpful conversations, suggestions, and comments on earlier drafts. All errors remain mine. 


\section{CONTEXT: THE SOUTH AFRICAN ASYLUM REGIME AND THE CONSTITUTIONAL ROLE OF INTERNATIONAL LAW}

\section{A Introduction}

Just over two decades ago, South Africa (SA) adopted the Refugees Act 130 of 1998 (RA), which incorporated the Republic's global and regional obligations under international refugee law (IRL). In terms of the scope and content of protection it provided for refugees, the RA was progressive and advanced. The coming into force on 1 January 2020 of the Refugees Amendment Act 11 of 2017 (RAA 2017) substantively and detrimentally altered South Africa's refugee protection landscape, severely restricting access to the asylum regime and denying asylum-seekers substantive rights that had previously been available to them. Moreover, the amended RA withdraws status and protection from some refugees, recognised as such under IRL. Indeed, many of the new provisions arguably violate SA's international obligations and its Constitution.

This article appraises over two decades of South African asylum jurisprudence. Its analysis reveals significant gaps between the Republic's IRL commitments as expressed in the Preamble and substantive provisions of the RA and its policy realities for asylum-seekers - ultimately cemented by the enactment of the RAA 2017. Part I of this paper sheds light on the promise of refugee protection prior to the RAA 2017, juxtaposing it against actions of the South African Executive which have undermined and still do undermine access to asylum. Highlighting the prominent role of international law in SA's constitutional framework, the article probes the insubstantial part that IRL has played in asylum adjudication until now. Part II appraises the courts' endeavours to bridge protection gaps which the Executive's policies have (often deliberately) created regarding asylumseekers' process and substantive rights. Turning to the present and future, part III juxtaposes RAA 2017 provisions with IRL standards, as complemented and enhanced by international human rights law (IHRL), in five main areas: exclusion from refugee status; access to asylum; asylum processing centres and restrictions on movement; access to employment and education; and restrictions of political activities. In turn, part IV outlines three potential (non-exhaustive) constitutional grounds for challenging the RAA 2017 in SA courts: first, legislative inconsistency, irrationality, and the legality principle; second, disproportionate infringement of the Bill of Rights in view of SA's treaty obligations; third, the RAA 2017's manifestly retrogressive nature. Given the enhanced interpretive role of IRL \& IHRL, pursuant to s 1A of the RA as amended by the Refugees Amendment Act 33 of 2008 (RAA 2008), a clash between fundamental IRL tenets and RAA 2017 provisions appears irreconcilable. It is contended that, when called upon, SA courts must be prepared to declare certain RAA 2017 provisions (and their accompanying Regulations) as unconstitutional. Part V concludes.

\section{B Legislative commitment}

In 1954, Paul Weis bleakly described refugees as a 'vessel on the open sea ... not sailing under any flag'. In 2020, refugees seek legal recognition of their predicament pursuant to international standards; yet, it is national institutions, applying domestic legislation, to whom they most often turn for recognition and protection. In turn, host countries' compliance with their international obligations occasionally gives way to national considerations, and effective protection of rights for refugees depends both on access to asylum and on judicial remedies for legislative infractions. 
On 12 June 1996, post-Apartheid South Africa ratified the 1951 Geneva Convention relating to the Status of Refugees (1951 Convention) ${ }^{1}$ and the 1967 New York Protocol relating to the Status of Refugees (1967 Protocol) $)^{2}$, the latter treaty removing the temporal and regional restrictions on the 1951 Convention's application. ${ }^{3}$ Article 1A(2) of the 1951 Convention stipulates that the term 'refugee' 'shall apply to any person who ... owing to well-founded fear of being persecuted for reasons of race, religion, nationality, membership of a particular social group or political opinion, is outside the country of his nationality and is unable or, owing to such fear, is unwilling to avail himself of the protection of that country. ${ }^{4}$ Earlier, on 15 December 1995, South Africa became party to the 1969 Convention Governing the Specific Aspects of Refugee Problems in Africa (OAU Convention), ${ }^{5}$ which broadens the definition of a 'refugee' in the region beyond the 1951 Convention definition to 'also apply to every person who, owing to external aggression, occupation, foreign domination or events seriously disturbing public order in either part or the whole of his country of origin or nationality, is compelled to leave his place of habitual residence in order to seek refuge in another place outside his country of origin or nationality' ${ }^{6}$ (emphasis added).

In 1998, SA enacted the RA, which came into force on 1 January 2000. The Act aims to 'give effect ... to the relevant international legal instruments, principles and standards relating to refugees; to provide for the reception into South Africa of asylum seekers; to regulate applications for and recognition of refugee status; to provide for the rights and obligations flowing from such status; and to provide for matters connected therewith'. ' Section 3 of the RA broadly adopts the OAU Convention's expanded refugee definition to determine eligibility

28 July 1951, 189 United Nations Treaty Series 150.

31 January 1967, 267 United Nations Treaty Series 606.

3 Apartheid South Africa had no legislative protection for asylum-seekers. J Handmaker 'Public Interest Litigation for Refugees in South Africa and the Potential for Structural Change' (2011) 27 South African Journal on Human Rights 65.

$4 \mathrm{Or}$, in the case of stateless persons, if such a person is 'outside the country of his former habitual residence as a result of such events' and 'is unable or, owing to such fear, is unwilling to return to it'.

510 September 1969, 1011 United Nations Treaty Series 45. Five African countries are not parties to the 1951 Convention: Cape Verde, Comoros, Eritrea, Libya, and Mauritius. Libya and Cape Verde acceded to the 1969 Convention whereas Comoros and Mauritius ratified it. Only Eritrea has not become party to either the 1951 Convention or the OAU Convention.

6 Ibid art 1(2). This article does not address the substance of the refugee definition and interrelations between the OAU Convention and the 1951 Convention refugee definitions. See e.g. M Sharpe The Regional Law of Refugee Protection in Africa (2018) 86-88(Presents three alternative approaches: first, a sequential approach, whereby the OAU expanded definition is considered only if an individual does not qualify for refugee status under the 1951 Convention, which is linguistically supported by para 9 of the OAU Convention's preamble and by the ordering of the definitions in art 1; second, the nature of the claimant's flight dictates the definitional choice; and, third, an interpretation sensitive to pragmatic considerations, such as 'mass-influx' situations which may call for an art 1(2)) application). Regarding interpretive practices in SA, see e.g., T Wood 'Who is a Refugee in Africa? A Principled Framework for Interpreting and Applying Africa's Expanded Refugee Definition' (2019) 31(2-3) International Journal of Refugee Law 290, 302(Notes the Western Cape High Court judgment in Harerimana v Chairperson of the Refugee Appeal Board [2013] ZAWCHC 209, (2014) (5) SA 550 (WCC), which held that the Refugee Appeal Board (RAB) erred by failing to consider refugee claims under the OAU definition. Wood suggests that this was 'the continent's first explicit judicial consideration of the [OAU] definition's terms and application'.).

7 In addition see the Preamble to the RA, proclaiming its purpose is to 'give effect to the relevant international legal instruments to which South Africa is party and the principles and standards relating to refugees contained within'. RA s 3 incorporates the above OAU refugee categories; s 3(a) adds tribe to the five 1951 Convention 
for refugee status. ${ }^{8}$ The RA and its implementing 2000 Refugee Regulations (the 2000 Regulations $)^{9}$ generally follow the 1951 Convention's structure, listing exhaustive grounds for exclusion from (s 4) and cessation of (s 5 ) refugee status, before turning to asylum procedures and ensuing rights. It could be argued that, by enacting the RA, SA was seeking to fulfil its IRL protection obligations in good faith.

\section{Policy realities}

Taking stock of two decades since the commencement of the RA, it appears that SA has significantly backtracked from that legislative commitment. ${ }^{10}$ It has done so through the adoption of restrictive policies, unfavourable position papers, and ultimately the enactment of the RAA 2017 which, as part III shows, contains serious breaches of IRL, as complemented by IHRL. The judgments considered in part II reveal that the Executive's policies have curtailed effective access to asylum, inter alia, through pre-screening procedures; refusal to renew permits originally issued at another Refugee Reception Office (RRO) elsewhere in SA; closure of RROs and foot-dragging in implementation of court orders that instructed their re-opening, as well as corruption in their operation; and refusal to issue permits to delayed applicants. ${ }^{11}$ In terms of asylum-seekers' substantive rights, the Executive has attempted to restrict access to employment, education, basic medical care, and marriage (at least) until and unless asylum-seekers are formally recognised as refugees. Moreover, in the light of declining refugee recognition rates (see part III), the refusal to issue asylum-seeker permits to appellants while their appeals are pending, coupled with significant backlogs in reviewing appeals, has left many in legal limbo. The Executive has also rejected asylum-seekers' applications for temporary and permanent residence permits that would afford them greater security of residence. Concomitantly, detention practices have breached legislatively prescribed periods and the requirement to keep immigration detainees separately from criminal detainees. Most distressingly, SA authorities have attempted to deport persons whose cases were pending. The

reasons of persecution; s 1(xxi) defines 'particular social group' in the 1951 Convention to include gender and sexual orientation.

8 The refugee definition in s 3 of the RA goes further than the OAU definition, adding the words 'or disrupting' to the ground of 'events seriously disturbing public order'.

9 Refugee Regulations (Forms and Procedure), published on 6 April 2000 in Government Gazette No 21075.

${ }_{10}$ Generally also see F Khan and T Schreier (eds) Refugee Law in South Africa (2014).

${ }^{11}$ For historical context regarding RROs, see R Amit No Way In: Barriers to Access, Service and Administrative Justice at South Africa's Refugee Reception Offices (2012), available at https://ssrn.com/abstract=3274020. Regarding corruption in the asylum process, see R Amit Queue Here for Corruption, Measuring Irregularities in South Africa's Asylum System (2015), available at www.lhr.org.za/sites/lhr.org.za/files/lhracms_report-queue_here_ for_corruption-july_2015.pdf; R Amit Paying for Protection: Corruption in South Africa's Asylum System (2015), available at www.migrationpolicy.org/article/paying-protection-corruption-south-africas-asylumsystem; R Amit \& N Kriger 'Making Migrants "Il-Legible": The Policies and Practices of Documentation in Post-Apartheid South Africa' (2014) 40(1) Kronos 269. 
above measures, which the 2016 Green Paper $^{12}$ and 2017 White Paper ${ }^{13}$ broadly endorse, reveal an ideological turn from the welcoming spirit of the RA.

With refugee crises the world over, restrictive asylum policies may be (considered) electorally popular. Moreover, despite a history of persecution that is deeply embedded in the majority population's consciousness, and despite the support that southern African countries offered to the liberation movement in the struggle against Apartheid, ${ }^{14}$ a 2018 Pew research survey revealed greater resistance to welcoming refugees in South Africa than in most surveyed countries. Responding to the question 'thinking about immigration, would you support or oppose [your country] taking in refugees from countries where people are fleeing violence and war', 48\% supported the proposition and 50\% opposed it. ${ }^{15}$ The year 2019 has also seen a resurgence of xenophobic attacks against migrants, including refugees, at a level not witnessed in SA since 2008. ${ }^{16}$

\section{South Africa's 'international law friendly' Constitution}

The South African Constitution has been described as 'international law friendly'. ${ }^{17} \mathrm{It}$ pronounces that (all) courts must consider international law in interpretation of the Bill of Rights; ${ }^{18}$ that when interpreting legislation, courts must prefer any reasonable interpretation that is consistent with international law over any other interpretation ${ }^{19}$; and that customary international law (CIL) must be treated as law in SA, except where it is in conflict with the Constitution or an Act of Parliament. ${ }^{20}$ Debates have arisen in SA as to the desirable

12 Department of Home Affairs (DHA) Green Paper on the International Migration for South Africa (21 June 2016), available at http://www.dha.gov.za/files/GreenPaper_on_InternationalMigration-\%2022062016.pdf. As early as 2012, the ANC's Peace and Stability: Policy Discussion Document (2012) 5 stated that '95\% of asylum seekers came for economic rather than protection-based motives', available at http://www.anc.org.za/ docs/discus/2012/peacev.pdf.

13 DHA White Paper on the International Migration for South Africa (July 2017) 27, available at http://www.dha. gov.za/WhitePaperonInternationalMigration-20170602.pdf notes that 'South Africa continues to receive a high volume of asylum seekers, and over 90 per cent do not qualify for refugee status'.

14 J Handmaker, Lee Anne de la Hunt, \& Jonathan Klaaren (eds) Advancing Refugee Protection in South Africa (2008) 4(Notes that the new SA's refugee policy was crafted by a government largely staffed by former refugees).

15 The EU median was: $77 \%$ support, 21\% oppose (Hungary being the outlier: 32\% support, 54\% oppose). Elsewhere, globally, only Russia and Israel had worse refugee support levels, available at https://assets. pewresearch.org/wp-content/uploads/sites/1/2018/09/18141059/FT_18.09.19_AttitudesRefugees_Topline.pdf.

16 For example, see Human Rights Watch 'South Africa: Punish Xenophobic Violence' (13 September 2019), available at https:/www.hrw.org/news/2019/09/13/south-africa-punish-xenophobic-violence. The South African Human Rights Commission launched an Inquiry on Violent Attacks Targeted toward Non-Nationals: With a focus on Long Distance Truck Drivers (concept note on file with author). For historical accounts see eg JP Misago 'Responding to Xenophobic Violence in Post-Apartheid South Africa: Barking up the Wrong Tree?' (2016) 2(2) African Human Mobility Review 443; S Mlilo and JP Misago Xenophobic Violence in South Africa: 1994-2018, An Overview (March 2019), available at https://www.xenowatch.ac.za/wp-content/uploads/2019/03/XenophobicViolence-in-South-Africa-1994-2018_An-Overview.pdf.

17 E Cameron 'Constitutionalism, Rights, and International Law: The Glenister Decision' (2013) 23(2) Duke Journal and Comparative \& International Law 389 (Notes that, instead of treating international law as an enemy, the Constitution embraced it). See also Law Society of South Africa v President of Republic of South Africa [2018] ZACC 51, 2019 (3) SA 30 (CC) at para 4 (suggesting that international law's 'centrality in shaping our democracy is self-evident').

18 Section 39(1)(b) of the Constitution of the Republic of South Africa, 1996 (Constitution).

19 Ibid s 233.

20 Ibid s 232 . 
methodology of identifying relevant sources of international law ${ }^{21}$ and the (differential) weight ${ }^{22}$ to be accorded to binding and non-binding ${ }^{23}$ international instruments in interpreting the Constitution. ${ }^{24}$

Yet, these important challenges would not have ordinarily arisen when it came to the interpretation and application of IRL (and IHRL) in an asylum context, given the RA's bespoke interpretive framework which enumerates the key treaty sources. Since its inception, $s 6$ of the RA has stipulated that the Act 'must be interpreted and applied with due regard' to the 1951 Convention, 1967 Protocol, 1969 OAU Convention, 1948 Universal Declaration of Human Rights, ${ }^{25}$ and 'any other international human rights law instrument to which the Republic is party'. ${ }^{26}$ In turn, art 5 of the 1951 Convention stipulates that 'nothing in this Convention shall be deemed to impair any rights and benefits granted by a Contracting State to refugees apart from this Convention'. Given the favourable general constitutional interpretive framework and the RA-specific interpretive instruction, one could have expected IRL, reinforced and complemented by relevant international human rights instruments, ${ }^{27}$ to have played a dominant role in SA courts' asylum case law. Has it?

${ }^{21}$ D Tladi 'Interpretation and International Law in South African Courts: The Supreme Court of Appeal and the Al Bashir Saga' (2016) 16 African Human Rights Law Journal 310, 336(Contends that, SA courts have, generally, struggled with the methodological questions of the interpretation and identification of international law. He argues that courts should apply the international rules of interpretation and identification of international law when dealing with international law, such as arts 26 (good faith) and 31 (interpretation) of the Vienna Convention on the Law of Treaties, to which South Africa is not a party). See also Law Society (note 17 above) (Notes at para 36 that 'Although South Africa is not party to the Vienna Convention, it is bound by some of its major provisions...like article...26').

22 Government of RSA v Grootboom [2000] ZACC 19, 2001 (1) SA 46 (CC) at para 26('relevant international law can be a guide to interpretation but the weight to be attached to any particular principle or rule of international law will vary').

23 S v Makwayane [1995] ZACC 3, 1995 (3) SA 391 (CC) at para 35(Refers to 'international agreements and customary international law' as a 'framework' within which the Bill of Rights 'can be evaluated and understood' and thereby confirming its relevance to Bill of Rights interpretation).

${ }^{24}$ The debate was largely prompted by the judgment in Glenister $v$ President of the Republic of South Africa [2011] ZACC 6, 2011 (3) SA 347 (CC). For discussion see J Tuvoninen 'The role of international law in constitutional adjudication: Glenister v President of the Republic of South Africa' (2013) 130(4) South African Law Journal 661.

25 General Assembly A/Res/217(III) (10 December 1948). Article 14 proclaims a right 'to seek and enjoy asylum from persecution'. Unlike a (growing) number of countries, South Africa does not have a constitutional right to asylum and has not constitutionalised 1951 Convention rights. For discussion see S Meili 'The Constitutional Right to Asylum: The Wave of the Future in International Refugee Law?' (2018) 41 Fordham International Law Journal 383.

26 South Africa is party to, among others, the core seven International human rights treaties: Covenant on Civil and Political Rights (1966)(ICCPR); Covenant on Economic, Social and Cultural Rights (1966)(ICESCR); Convention on the Elimination of All Forms of Discrimination against Women (1979)(CEDAW); Convention on the Rights of the Child (1989)(CRC); Convention Against Torture and Other Cruel, Inhuman or Degrading Treatment or Punishment (1984)(CAT); Convention on the Elimination of All Forms of Racial Discrimination (1966)(CERD); Convention on the Rights of Persons with Disabilities (2006)(CPRD). Ratification details available at https://indicators.ohchr.org/.

27 Regarding the interrelations between IRL and IHRL, the key premise that guides this article, following a systemic integration approach to treaty interpretation, is that IHRL complements IRL and aids its interpretive construction. See e.g. V Chetail 'Human Rights Law and Refugee Protection' in C Costello, M Foster \& J McAdam (eds) The Oxford Handbook of International Refugee Law (forthcoming) (positing that 'no one contests today that, in states parties to the [1951] Geneva Convention, refugees are simultaneously protected by specialised treaties of refugee law as a specific category of international concern, as well as by generalist 


\section{E Judicial rectifications?}

South Africa is a major refugee-hosting country, predominantly from elsewhere in Africa. ${ }^{28}$ It has litigious civil-society organisations which have been making extensive use of constitutionally protected standing, extended to 'anyone acting in the public interest', ${ }^{29}$ and a (duly) expansive jurisdictional notion ${ }^{30}$ which accommodates legal challenges to measures such as those described in subsection C above at all judicial levels - High Courts, Supreme Court of Appeal, and ultimately the Constitutional Court (the Court). ${ }^{31}$ In their asylum adjudication over the past 20 years, SA courts have been forced to square the protective premises of the RA with Executive policies designed to limit access to asylum procedures and to deny asylum-seekers substantive rights. In so doing, SA courts have extended constitutional protection to all those physically in the Republic, irrespective of their legal status. ${ }^{32}$ They have utilised the fundamental IRL principle of nonrefoulement, recognised in s 2 of the RA, to bridge a protection gap between an 'asylum-seeker' (per the RA) and an 'illegal foreigner' (per the Immigration Act 11 of 2002 [IA]), enabling access to the asylum process through insistence on issuance or renewal of asylum permits. Courts have also construed the constitutional right to dignity to facilitate asylum-seekers' (partial) access to employment, to basic medical care, to education, and to marry South Africans, which the Executive sought to deny through directives, regulations, and other policies. ${ }^{33}$

treaties of human rights law as a result of their applicability to all human beings'). Describing conflicts of norms between IHRL and IHL as 'extremely rare', Chetail argues IHRL 'considerably enriches the material scope of international protection by granting a broad range of supplementary rights that are not guaranteed by the Geneva Convention'. IHRL's role in interpretation of the refugee definition falls outside this article's scope. For discussion see B Burson \& DJ Cantor (eds) Human Rights and the Refugee Definition (2016).

${ }^{28}$ In 2018, SA hosted 89285 recognised refugees and 184203 asylum-seekers, primarily from the DRC, Ethiopia, Somalia, and Zimbabwe in Africa, and from Bangladesh and Pakistan in Asia. UNHCR, 'Global Trends: Forced Displacement in 2018' available at https://www.unhcr.org/afr/statistics/unhcrstats/5d08d7ee7/unhcr-globaltrends-2018-html. According to the DHA, on 30 June 2019, there were 186210 s 22 holders - 60\% of whom have had applications pending for more than five years. See 'Answer to Parliamentary Question NW1586 of 9 December 2019', available at https://pmg.org.za/committee-question/12936.

29 Lawyers for Human Rights \& Another v Minister of Home Affairs \& Another [2004] ZACC 12, 2004 (4) SA 125 (CC) $(L H R)$ at paras 14-15(Notes that s 38 of the Constitution 'introduc[es] a radical departure from the common law in relation to standing', including 'expressly allow[ing] court proceedings by individuals or organisations acting in the public interest.')

30 Ibid at para 26(Holds that the Constitution protects 'foreign nationals who are physically in our country but who have not been granted permission to enter and have therefore not entered the country formally').

31 Compare LB Landau \& R Amit 'Wither Policy? Southern African Perspectives on Understanding Law, "Refugee" Policy and Protection' (2014) 27(4) Journal of Refugee Studies 534, 535 (Argues that, despite SA having some of the most progressive refugee legislation in the world, refugees and asylum-seekers are severely constrained in realising their legislated rights: legal failures cannot effectively be addressed solely through legal means).

${ }^{32} L H R$ (note 29 above) at para 27(Holds that physical presence entitles persons to constitutional rights irrespective of whether their presence is legal, though refraining from determining whether 'people who seek to enter South Africa by road at border posts are entitled to the rights under our Constitution if they are not allowed to enter the country'.) Also see Abdi \& Another v Minister of Home Affairs \& Others [2011] ZASCA 2, 2011 (3) SA 37 (SCA)(Determines that asylum-seekers held at an inadmissible facility at a point of entry enjoy the protection of the RA and the courts).

33 Compare R Amit '(Dis)placing the Law: Lessons from South Africa on Advancing U.S. Asylum Rights' (2018) 20 Loyola Journal of Public Interest Law 1 (Argues that court victories prove hollow, given the DHA not only routinely fails to implement court orders, but also continues to engage in illegal practices, and suffers no repercussions for its defiance). 
Yet, in their asylum adjudication, SA courts have also practised a form of 'decisional minimalism'34 that is 'cautious, incremental, particularistic and theoretically modest' ${ }^{35}$ regarding their use of international law. They have rarely (if ever) used the international instruments listed in the RA as their primary interpretive source. An analysis of the numerous cases referenced in this article reveals that only three judgments mentioned in passing s 6(1) of the RA's 'due regard' interpretive requirement, and none have proceeded to consider properly its normative significance. Cursory references to s 39(1)(b) or s 233 of the Constitution notwithstanding, ${ }^{36}$ one is hard-pressed to find 'real consideration' of IRL (or indeed IHRL) treaties, ${ }^{37}$ let alone an 'international-law-first approach ${ }^{38}$ in which tenets of IRL are the starting premise for substantive appraisal ${ }^{39}$ and where, critically, the logic of international protection is applied. Indeed, some judgments merely allude to SA's international obligations without spelling them out. ${ }^{40}$

Had South African courts seriously engaged with the s 6(1) of the RA interpretive sources, they would have sought to question the normative premise underlying the policy measures affecting asylum-seekers that they had been called upon to review: namely, that until and unless a person is granted refugee status, however long that process takes and irrespective of causes for delay, asylum-seekers are not entitled to substantive protections attached to (recognised) refugee status. Yet, a fundamental tenet of IRL is that 'the recognition of refugee status is a

${ }^{34}$ Compare J Tuovinen 'What to Do with International Law? Three Flaws in Glenister' (2014) 5 Constitutional Court Review 435(Critiques the prominence of international law in that judgment in lieu of an engagement with substantive rights).

35 I Currie 'Judicious Avoidance' (1999) 15(2) South African Journal on Human Rights 138(Appraises the post-Apartheid Court's first years). See also A Cockrell 'Rainbow Jurisprudence' (1996) 12 South African Journal on Human Rights 1 (Suggests that in the early days of the Court's jurisprudence, it was unable or unwilling to engage in the 'first order moral and political reasoning' that constitutional interpretation required).

${ }^{36}$ For instance, see Minister of Home Affairs v Ruta [2017] ZASCA 186, 2018 (2) SA 450 (SCA) at para 31.

${ }^{37}$ H Strydom \& K Hopkins 'International law' in S Woolman et al (eds) Constitutional law of South Africa: Vol 2 (2013) 30-11(Notes in general that, while South African courts have been referencing international human rights law, there is little evidence of 'real consideration').

${ }^{38}$ Compare A Coutsoudis \& M du Plessis 'We Are All International Lawyers; Now What? Taking Seriously the Constitutional Injunction to Integrate International Law Obligations into South African Law' (2020) 10 Constitutional Court Review 155 (Presents a case for an international-law-first approach in constitutional jurisprudence).

39 Compare Mail and Guardian Media Ltd \& Others v Chipu NO \& Others [2013] ZACC 32, 2013 (6) SA 367 (CC) at para 22 (Commences the 'background' section with an outline of the relevant international law norms and then returns to analyse the exclusion clause). In Tantoush v Refugee Appeal Board [2007] ZAGPHC 191, 2008 (1) SA 232 (T) at para 112, the High Court noted that counsel for the applicant's urged the court to adopt a contextual approach 'having regard to the provisions and intention of the treaty ... expressly mandated by section 6(1) of the Act'. In Tshiyombo v Refugee Appeal Board [2015] ZAWCHC 170, 2016 (4) SA 469 (WCC) at para 28, the High Court referred to the Act's long title, Preamble, and s 6. Regarding burden of proof, Tantoush and Tshiyombo both reference the UHNCR Handbook on Procedures and Criteria for Determining Refugee Status and Guidelines on International Protection (revised February 2019), at paras 196-197 and at para 37, respectively (UNHCR Handbook on Procedures).

${ }^{40}$ For example, see Somali Association of South Africa \& Others v Limpopo Department of Economic Development Environment Tourism \& Others [2014] ZASCA 143, 2015 (1) SA 151 (SCA) at para 43(Notes that 'the frustration experienced by the authorities as they deal with a burgeoning asylum seeker and refugee population must not blind them to their constitutional and international obligations'). Far fewer judgments refer to IHRL instruments. Compare T Daly 'Kindred Strangers: Why has the Constitutional Court of South Africa Never Cited the African Court on Human and Peoples' Rights?' (2019) 9 Constitutional Court Review 387. 
declaratory act', ${ }^{41}$ notwithstanding the practical significance of recognition. ${ }^{42}$ The UNHCR Handbook on Procedures famously postulates that

A person is a refugee within the meaning of the 1951 Convention as soon as he fulfils the criteria contained in the definition. This would necessarily occur prior to the time at which his refugee status is formally determined. Recognition of his refugee status does not therefore make him a refugee but declares him to be one. He does not become a refugee because of recognition but is recognised because he is a refugee. . $^{3}$

Section 1(v) of the RA, which legislative amendments including the RAA 2017 have not modified, explicitly adopts this principle by defining an 'asylum seeker' as 'a person who is seeking recognition as a refugee' (emphasis added). ${ }^{44}$ In turn, s 27(a) of the RA pronounces that a refugee 'is entitled to a formal written recognition of refugee status' (emphasis added).

Ultimately, it is because recognition of a person as a refugee is declaratory that asylumseekers must enjoy unhindered access to a fair Refugee Status Determination (RSD) process, lest they should be exposed to refoulement prior to having their claims assessed. ${ }^{45}$ Having been granted such access, and following submission of an asylum application, asylum-seekers should be considered 'presumptive refugees' ${ }^{46}$ until and unless their claim has been duly and finally rejected following a fair procedure. Therefore, the onus is on host country authorities to justify why asylum-seekers whose applications are pending should be denied access to rights that are otherwise available to refugees, rather than assume this should be the legal default. Administrative backlogs and staffing shortages should not be 'rewarded' by relying on them as a basis for denial of rights. ${ }^{47}$

Yet, in cases where SA courts have quashed restrictive policy measures as unconstitutional or instructed the Executive to (re)issue asylum permits, they have not sought to appraise the compatibility of policies with IRL as such by interpreting the enumerated sources in s 6(1) of the RA; nor have they predicated their analysis on the declaratory nature of refugee status. It is contended that, had courts engaged properly with the Republic's treaty obligations, the protective outcome of certain judgments would be more durable: the normative foundations would have been laid for the inevitable constitutional appraisal of RAA 2017 provisions.

${ }^{41}$ For example, see Preamble of Directive 2011/95/EU of the European Parliament and of the Council of 13 December 2011 on Standards for the Qualification of Third-Country Nationals or Stateless Persons as Beneficiaries of International Protection, for a uniform status for refugees or for persons eligible for subsidiary protection, and for the content of the protection granted (recast) OJ 2011 No. L337/9 at para 21. Furthermore, Ruta v Minister of Home Affairs [2018] ZACC 52, 2019 (2) SA 329 (CC) at para 27 alluded to the declaratory nature of refugee status by noting that both de jure and de facto refugees are Convention refugees.

42 C Costello 'On Refugeehood and Citizenship' in A Shachar, R Bauböck, I Bloemraad, \& M Vink (eds) Oxford Handbook on Citizenship (2017) 729-730 (Posits that, 'being protected against refoulement often generates precarity, as it does not bring with it a particular status for the non-removable person ... the central concern of the Refugee Convention, as its full title indicates, is to recognise refugees as the bearers of a particular status').

43 UNHCR Handbook on Procedures (note 39 above) at para 28.

${ }^{44}$ In turn, s $1(\mathrm{xv})$ of the RA defines a 'refugee' as any person who has been 'granted asylum in terms of this Act'.

${ }^{45}$ UNHCR Note on International Protection (31 August 1993) at para 11.

46 J Vedsted-Hansen 'Non-Admission Policies and the Right to Protection: Refugees' Choice versus States' Exclusion?' in F Nicholson \& P Twomey (eds) Refugee Rights and Realities: Evolving International Concepts and Regimes (1999) 269, 275. See also Rv Uxbridge Magistrates Court \& Another, Ex Parte Adimi [1999] EWHC Admin 765 at para 16(Notes that art 31 ('Refugees unlawfully in the country') 'extends not only merely to those ultimately accorded refugee status but also to those claiming asylum in good faith (presumptive refugees) is not in doubt'.).

47 For example, see J Hathaway The Rights of Refugees under International Law (2005) 158 (Argues that 'genuine refugees may be fundamentally disadvantaged by the withholding of rights pending status assessment'.). 
Part II appraises core challenges to SA's asylum policies over the past two decades. It reveals how courts have utilised the Constitution to bridge (some) protection gaps but have largely refrained from employing SA's IRL obligations in their analyses, leaving the legal terrain (more) vulnerable to the adverse effects of RAA 2017.

\section{TWO DECADES OF ASYLUM ADJUDICATION: GAPS-BRIDGING}

\section{A The nonrefoulement conundrum}

Two intersecting regimes govern the treatment and status of persons seeking protection in SA: the RA and the IA. ${ }^{48}$ The IA distinguishes between 'foreigners' and 'illegal foreigners'. A foreigner 'means an individual who is neither a citizen nor a resident but is not an illegal foreigner'. An illegal foreigner 'means a foreigner who is in the Republic in contravention of this Act' (emphases added). Whereas 'foreigners' holding an asylum-seeker permit (renamed 'visa' for unspecified reasons by the RAA 2017) that is issued pursuant to s 22 of the RA are not considered 'illegal foreigners', those who, for procedural or substantive reasons, are denied permits or refused their renewal are at risk of deportation under the IA. As the Saidi and Arse judgments (see part IIB below) confirmed, in law, the mere refusal to issue or renew s 22 permits does not necessarily authorise immigration authorities to subject an asylum-seeker to the wrath of the IA; yet, practically, refusal or withdrawal of a s 22 permit may expose such an asylum-seeker to risks of arrest, detention, and deportation. ${ }^{49}$

The challenge in respect of 'illegal foreigners' arises due to $s$ of the RA, which gives primacy to nonrefoulement 'notwithstanding any provision of this Act or any other law to the contrary'..$^{50}$ The consequences are profound: even 'illegal foreigners' are normatively shielded by $s$, leaving them in legal limbo: they cannot be refouled, but until and unless they are issued a permit they cannot enjoy the rights accorded to asylum-seekers in legislation and

48 As amended by the Immigration Amendment Act No 13 of 2011. C Johnson 'Failed Asylum Seekers in South Africa: Policy and Practice' 2015 1(2) African Human Mobility Review 203(Argues that, de facto, the IA's regime renders immigration prospects to SA unattainable to most - if not all — low skilled workers). See also C Johnson \& S Carciotto 'The State of the Asylum System in South Africa' in M O'Sullivan \& D Stevens (eds) States, the Law and Access to Refugee Protection: Fortresses and Fairness (2017) 167(Points to an imbalance between 'restrictive immigration framework and the liberal refugee protection framework').

${ }^{49}$ Courts have considered challenges to detention practices of 'illegal migrants'. Minister of Home Affairs $v$ Rahim [2016] ZACC 3; (2016) (3) SA 218 (CC)(Holds that the MHA must have regard to international norms for the detention of those who fall foul of immigration regulation); Lawyers for Human Rights v Minister for Home Affairs \& Others [2017] ZACC 22; 2017 (5) SA 480 (CC)(Holds that ss 34 (1)(b) and (d) of the IA violate s 35(2)(d) of the Constitution, guaranteeing the right to challenge detention in court, as well as s 12(1), guaranteeing freedom and security of the person, including the right not to be detained without trial; the declaration of invalidity was suspended for 24 months). For challenges facing migrants in SA generally see e.g. T Alfaro-Velcamp \& M Shaw 'Please go HOME and BUILD Africa: Criminalising Migrants in South Africa' (2016) 42(5) Journal of African Studies 983(Describes the criminalisation of migrants in SA through compelling them to purchase documents through illicit means, and the SA police service conducting raids and illegally detaining migrants).

50 Section 2 reads: 'Notwithstanding any provision of this Act or any other law to the contrary, no person may be refused entry into the Republic, expelled, extradited or returned to any other country or be subject to any similar measure, if as a result of such refusal, expulsion, extradition, return or other measure, such person is compelled to return to or remain in a country where - (a) he or she may be subjected to persecution on account of his or her race, religion, nationality, political opinion or membership of a particular social group; or (b) his or her life, physical safety or freedom would be threatened on account of external aggression, occupation, foreign domination or other events seriously disturbing or disrupting public order in either part or the whole of that country.' 
judicial pronouncements. As the Ruta judgment stated, "[t]hough an asylum seeker who is in the country unlawfully is an "illegal foreigner" under the Immigration Act, and liable to deportation, the specific provisions of the Refugees Act intercede to provide imperatively that, notwithstanding that status, his or her claim to asylum must first be processed under the Refugees Act.' ${ }^{51}$

Part IIB considers the utilisation by courts of nonrefoulement to facilitate access to the SA asylum procedure. Part IIC turns to asylum-seekers' substantive rights. Fundamentally, s 27 of the RA stipulates refugees' access to (certain) rights but speaks not of asylum-seekers with the Executive's default position being denial of such rights. Whereas the SA judiciary has extended many such rights to asylum-seekers, rarely has it utilised IRL tenets in so doing.

\section{B Access to asylum: jurisdiction, refugee reception offices, and asylum permits}

\section{An 'inadmissible facility' at/near the SA border}

The first practical hurdle to accessing asylum procedures in SA is admission. Section 2 of the RA lists refusal of entry to the Republic as one of the manifestations of refoulement, following express stipulation to that effect in the OAU Convention (viz. the 1951 Convention). The Supreme Court of Appeal (SCA) held that asylum applicants in an 'inadmissible facility' at a Port of Entry (PoE) into the Republic enjoy the protection of the RA and of the courts, and that they should be given 'every reasonable opportunity' to apply. ${ }^{52}$ Importantly, the court postulated that 'refusing a refugee entry to this country, and thereby exposing her or him to the risk of persecution or physical violence in his home country is in conflict with the fundamental values of the Constitution. ${ }^{53}$

\section{Issuance of appointment slips and 'pre-screening' procedure}

For in-country applicants, the key challenge to effective protection from refoulement is having access to an RRO where a Refugee Status Determination Officer (RSDO) issues them an asylum-seeker permit. Section 21 of the RA stipulates that 'An application for asylum must be made in person in accordance with the prescribed procedures to a Refugee Reception Officer at any Refugee Reception Office'. In turn, officers are required to assist asylum seekers in filling out their applications and to issue them permits. ${ }^{54}$

Yet, in the early 2000s, the Johannesburg and Pretoria RROs implemented two policies that undermined access to the asylum procedure: first, an 'appointment system' whereby applicants were given an appointment slip dated as far away as six months to a year; until their appointment date, applicants would remain 'illegal foreigners' and potentially liable to be arrested, detained, and deported pursuant to ss 32, 33 and 34 of the IA. Second, a 'pre-screening' process whereby applicants had to fill a form at a RRO car park without any assistance and without the benefit of interpreters; the form had two questions (why they were applying for asylum, and why they left their country/what would happen if they returned) and, based on their answers, RSDOs made decisions in their cases. The Transvaal High Court held both policies to be 'unconstitutional and unlawful in respect of the manner of scheduling

\footnotetext{
51 Ruta (note 41 above) at para 43.

52 Abdi (note 32 above).

53 Ibid at para 2.

54 RA s 21 regulating the issuance of $s 22$ permits.
} 
appointments and in respect of the pre-screening method adopted'..$^{55}$ It emphasised that ' $n$ ] o amount of administrative inconvenience can absolve the respondents of their legal and constitutional responsibility'. ${ }^{56}$ Disappointingly, an appointment slip system was introduced in 2018 at the Port Elizabeth RRO, resulting in yet another successful court challenge. ${ }^{57}$

\section{Refusal to renew a permit originally issued at another $R R O$}

Many asylum-seekers will have entered SA, received an asylum permit at an RRO in one part of the country, and landed up residing elsewhere, for family or employment reasons. The Cape Town RRO (CTRRO) refused to renew asylum permits issued at other RROs, leaving asylumseekers in possession of expired permits, susceptible to immigration control. The policy was successfully challenged, ${ }^{58}$ yet the Western Cape High Court judgment, ordering the renewal of permits, remains overshadowed by the failure to re-open the CTRRO (see part IIB5 below).

\section{Staffing shortages at RROs}

Access to the asylum process was further curtailed by rationing daily application numbers at RROs. In Kiliko, ${ }^{59}$ Congolese citizens argued that the CTRRO accepted only 20 asylum applications each day. Rejecting this policy, the High Court held that 'foreigners were entitled to all the fundamental rights entrenched in the Bill of Rights, save those specifically reserved for South African citizens' and that their 'illegal foreigner' status (absent s 22 permit) 'impacted, or threatened to impact' on their 'right to human dignity' and on their 'freedom and security'. ${ }^{60}$ It emphasised that SA 'was obliged, in terms of the international instruments to which it was a party [without specifying which], the Refugees Act and the provisions of ss 7(2) and 195 of the Constitution, to provide adequate facilities to receive, expeditiously consider and issue asylum-seeker permits.' ${ }^{61}$

\section{Closure of RROs in Cape Town and Port Elizabeth}

Given SA's manifold Points of Entry (PoEs), ${ }^{62}$ ensuring effective access to asylum requires operating RROs throughout the Republic. Before 2011, there were six active RROs: Johannesburg, Pretoria, Port Elizabeth, Cape Town, Durban, and Musina (close to the Zimbabwean border). Yet, in May 2011, the Johannesburg RRO closed entirely, in October 2011 the Port Elizabeth RRO closed to new applicants, and in July 2012 the CTRRO closed to new applicants. Consequently, asylum-seekers already in $S A$, residing in the Western and Eastern Cape, had to frequently travel to Pretoria, Durban or Musina to renew their permits;

55 Tafira $v$ Ngozwane 2006 ZAGPHC 136 (TPD) at 46.

56 Ibid at 22.

${ }^{57}$ Huda \& Another v Minister of Home Affairs (PEHC, unreported case no. 2434/2019).

58 Ntumba Guella Nbaya v Director-General of the Department of Home Affairs (WCHC, unreported case no. 6534/15) (copy with author)(Re challenges arising for families due to difficulties regarding marriage certificates). See also Scalabrini Centre of Cape Town v Minister of Home Affairs (WCHC, unreported case no. 5242/2016) (copy with author) discussed in K Moult 'Sally Gandar and Popo Mfubu: on the record' (2019) 68 South Africa Crime Quarterly 41(Challenges joint application procedures for families).

59 Kiliko \& Others $v$ Minister of Home Affairs \& Others [2008] ZAWCHC 124, 2006 (4) SA 114 (C).

${ }^{60}$ Ibid at paras 27-28.

61 Ibid at para 28.

${ }_{62}$ A list of PoEs is available at http://www.dha.gov.za/index.php/immigration-services/south-african-ports-of-entry. 
and applicants arriving through Western and Eastern Cape PoEs and issued there, as required, an asylum transit permit, had to travel significant distances at great expense within a short period to avoid becoming 'illegal foreigners'.

The closures of RROs in Port Elizabeth and Cape Town prompted judicial challenges (two in the case of the latter) that ultimately led courts to order their re-opening. ${ }^{63}$ In Somali Association, ${ }^{64}$ the SCA noted in respect of the closure of the Port Elizabeth PoE that ' $[T]$ he asylum application process is invariably a protracted one. Timely access to an RRO is thus critical not just for asylum seekers to legalise their stay in this country, but also for the effective protection of their rights. ${ }^{65}$ The SCA highlighted the adverse effect of the [Port Elizabeth] RRO closure on 'asylum-seekers' ability to choose their place of residence, not least in light of their need to join family, acquaintances and communities that are already established and who are able to help support them on arrival'. ${ }^{66}$ The court stated that 'repeated visits to a distant RRO also have the potential to jeopardise the employment and job security of an asylum seeker. ${ }^{\text {'67 }}$

As for the closure of the CTRRO, in Scalabrini (I), the SCA was reticent to order its re-opening: instead, it required the Director-General to consult with interested parties. The SCA was sympathetic to the respondents, noting that ' $[t]$ he obligations of the government to refugees are neither unrestrained nor unconfined. The material resources of governments are limited.' According to Willis J, there cannot be, inherently, a 'legitimate expectation ... on the part of anyone to have an RRO in any specific geographic location in the country, including Cape Town'. ${ }^{68}$ The judgment gave the Director-General time to consult with interested parties before deciding on the future of the RRO.

Several years of closure on, a second challenge ensued (Scalabrini $\left.(I I)^{69}\right)$. This time, the SCA ordered the re-opening of the CTRRO by 31 March 2018 'to ensure the immediate protection of their [asylum-seekers'] rights and the determination of their status in accordance with international standards' ${ }^{70}$ The DHA Director-General argued that 'refugee services were being abused by economic migrants' since $77 \%$ of applications at that office were rejected'. The SCA rejected this claim, noting that, on its own terms, the statement implies 'denial of access to a refugee reception office to $23 \%$ of genuine asylum seekers' and, consequently, denying them

${ }_{63}$ At the time of writing, despite the SCA order in Scalabrini (II) (note 69 below), the CTRRO had still not received any new applications: Reply to Question NW1456 to the Minister of Home Affairs (24 December 2019) (Notes that a lease agreement could not be finalised and that once finalised the building obtained will need to be refurbished before the office can be re-opened). Moreover, despite the Nbaya court order, the CTRRO initially refused to renew asylum-seekers' permits issued at other RROs. It then began renewing such permits with one month's validity, until such time as the relevant asylum file was transferred to the CTRRO. Meanwhile, asylumseekers whose permits had expired were taken to the police station; were required to attend a court hearing; and issued with an 'admission of guilt' fine. The Scalabrini Centre launched litigation in respect of both the failure to comply with Scalabrini (II) and the failure to properly implement Nbaya, seeking the appointment of a Special Master to oversee DHA compliance (copy on file with author).

${ }^{64}$ Minister of Home Affairs \& Others $v$ Somali Association of South Africa Eastern Cape \& Another [2015] ZASCA 35, 2015 (3) SA 545 (SCA).

65 Ibid at para 4.

${ }^{66}$ Ibid at para 28.

${ }^{67}$ Ibid at para 29.

${ }^{68}$ Minister of Hone Affairs \& Others $v$ Scalabrini Centre [2013] ZASCA 134, 2013 (6) SA 421 (SCA) at para 84.

69 Scalabrini Centre \& Others v Minister of Home Affairs and Others [2017] ZASCA 126, 2018 (4) SA 125 (SCA).

70 Ibid at para 35 . 
economic opportunities in Cape Town; it held that the RA 'reveals a clear, general orientation towards the protection of the rights of asylum seekers and refugees and their integration into South African society'. ${ }^{71}$

The CTRRO closure effectively imposed restrictions on asylum-seekers and refugees' choice of place of residence. The Scalabrini (II) judgment included a rare reference in South African jurisprudence to a substantive right in IRL, art 26 of the 1951 Convention, which stipulates that 'refugees lawfully in [the asylum country's] territory' should have 'the right to choose their place of residence and move freely within its territory subject to any regulations applicable to aliens generally in the same circumstances'. ${ }^{72}$ The SCA also referenced (but did not discuss) the interpretive requirement in $s 6$ of the RA. ${ }^{73}$ The judgment did not appraise, as per art 26, whether asylum-seekers and refugees are 'generally in the same circumstances' as other 'aliens' on whom such effective residence restrictions are not imposed.

\section{Refusal to issue a permit to a delayed applicant}

The Court in $R u t a^{74}$ considered the legal ramifications of a 15 months' delay in submitting an asylum application. Logically, the declaratory nature of refugee status must be front and centre of any such legal assessment, given that a decision to deny an applicant access to the asylum system merely on lateness grounds could effectively deny a 1951 Convention refugee status - and protection. The applicant, a Rwandan who entered SA irregularly via Zimbabwe, sought to apply for asylum following his arrest for a driving offence. In a compelling judgment, Cameron J held that a delay 'did not diminish his [Ruta's] entitlement to apply'75 even though '[i]t is a crucial factor in determining credibility and authenticity'. ${ }^{76}$

The judgment's reasoning heavily relies on the primacy of nonrefoulement within the RA structure. Moreover, the judgment acknowledges, though does not explicitly reference, the IRL notion of refugees sur place $e^{77}$ who 'enter the country of refuge on one basis' but 'thereafter supervening events in their country of origin involuntarily render them refugees' in respect of whom 'delayed' applications are a built-in feature of their predicament. ${ }^{78}$ The judgment also recognises that '[a]sylum seekers do not arrive only where they should, nor do they always have the opportunities and agency to claim what they should', yet it misses an opportunity to apply the non-penalisation principle in art 31(1) of the 1951 Convention, which enjoins host

71 Ibid at para 61.

72 Ibid at para 33 (Schippers AJA). Notably, SA has made no reservations to the application of 1951 Convention provisions; compare N Maple Rights at Risk: A Thematic Investigation into how States Restrict the Freedom of Movement of Refugees on the African Continent (2016) App 1: Table 4 (Seven African countries made reservations to art 26). For discussion of effective restrictions on movement due to being tied to an RRO see F Khan \& M Lee 'Policy Shifts in the Asylum Process in South Africa Resulting in Hidden Refugees and Asylum Seekers' (2018) 4(2) African Human Mobility Review 1205.

73 Ibid at para 19.

${ }_{74}$ Ruta (note 41 above).

75 Ibid at para 4.

${ }^{76}$ Ibid at para 56.

77 UNHCR Handbook on Procedures (note 39 above) at paras 94-96. Re refugees sur place, see also AI v Director of Asylum Seeker Management [2019] ZAWCHC 114 (2 September 2019)(States that the DHA must issue an asylum seeker permit to Burundian nationals whose initial applications for refugee status had been rejected, but who wished to lodge sur place applications).

${ }^{78}$ Ruta (note 41 above) at para 51. 
countries from imposing penalties on refugees for their unlawful entry or presence, provided certain criteria are met (for discussion, see part IIIB).

\section{Refusal to renew permits for asylum appellant}

Saidi ${ }^{79}$ concerned the CTRRO's refusal to renew the applicants' permits as they were awaiting the outcome of judicial reviews, following rejections of their asylum applications by RSDOs and failed appeals. The Court held by a majority (Jafta J dissenting) that s 22(3) of the RA mandates an RSDO to extend asylum-seekers' permits where the outcome of their application (read to mean final determination ${ }^{80}$ ) is pending; the judgment interpreted the word 'may' in the provision to mean 'must'. The judgment reiterated that '[w]ithout a temporary permit, there is no protection. This runs counter [to] the very principle of non-refoulement and the provisions of section 2' ${ }^{81}$ It emphasised that permits 'prevent undue disruption of a life of human dignity $\ldots$ and communing in ordinary human intercourse without undue state interference' ${ }^{82}$

The Court emphasised that 'courts must adopt a purposive reading of statutory provisions', noting the RA requires its interpretation to be made with 'due regard' to 1951 Convention, ${ }^{83}$ and referencing the s 233 constitutional requirement; yet, it did not frame the requirement to issue or extend s 22 of the RA permits in terms of a nonrefoulement obligation pursuant to art 33 of the 1951 Convention. Nevertheless, its judgment does cite (approvingly) Pinto de Albuquerque J's endorsement of the UNHCR Handbook on Procedures stipulation that 'the determination of refugee status is merely declaratory' in his separate opinion in Hirsi (a European Court of Human Rights judgment concerning interdiction at sea). ${ }^{84}$

\section{Refusal to (re)issue permits to detainees}

It was noted above that absent a s 22 permit, asylum-seekers as 'illegal foreigners' are susceptible to detention. Indeed, s 23(2) of the IA provides that '[d] espite anything contained in any other law' the holder of an asylum transit permit becomes, on expiry of the permit, an 'illegal foreigner' liable to be dealt with under the IA. Yet, s 21(4) of the RA stipulates that '[n] otwithstanding any law to the contrary, no proceedings may be instituted or continued against any person in respect of his or her unlawful entry into or presence in the country if that person has applied for asylum in terms of section 21(1) until a decision has been made on his or her application and that person has had an opportunity to exhaust his or her rights of review or appeal in terms of the Refugees Act'.

In Arse, ${ }^{85}$ the SCA ordered release from detention of an Ethiopian asylum-seeker whose permit had expired and whose application for asylum had been rejected by an RSDO but

79 Saidi v Minister of Home Affairs \& Another [2018] ZACC 9, 2019 (1) SA 1 (CC).

${ }^{80}$ Ibid at para 20.

81 Ibid at para 30 .

82 Ibid at para 18.

83 Ibid at para 29.

${ }^{84}$ Ibid at para 34. App No 27765/09 Hirsi Jamaa v Italy (GC) (23 February 2012) at pages 64-66. The judgment found that, Italy had breached its nonrefoulement obligations arising from art 3 of the European Convention on Human Rights, 4 November 1950, 213 United Nations Treaty Series 221, by intercepting at sea boats carrying Somalis and Eritreans and then returning to Libya without examining their protection claims, thereby exposing them to a risk of ill-treatment.

${ }^{85}$ Arse v Minister of Home Affairs [2010] ZASCA 9, 2012 (4) SA 544 (SCA). 
whose appeal was pending before the RAB. The SCA also ordered that he be issued with an asylum permit which would be valid until the final adjudication of an asylum claim, including all rights of appeal and review. Attempting to reconcile the two provisions, the SCA held that s 23(2) of the IA 'ceases to be of application when an asylum seeker permit is granted to an 'illegal foreigner". 86

$B u l a^{87}$ concerned the fate of 19 Ethiopian asylum-seekers who had arrived in Johannesburg and were detained shortly thereafter. After their transfer to the Lindela holding facility, and following a meeting with Lawyers for Human Rights, they had written to the DHA seeking to halt their impending deportation, demanding their release and an opportunity to apply for asylum. Absent a response, they sought judicial review. The SCA held that, 'once an intention to apply for asylum was evinced, the protective provisions of the RA...come into play and the asylum seeker is entitled as of right to be set free subject to the provisions of the [Refugees] Act' ${ }^{8}{ }^{8}$ It thus interdicted the Executive from deporting the applicants, declared their detention unlawful, ordered their release, and authorised their lawful stay for 14 days in order to apply for asylum at an RRO — where they would be issued a s 22 permit.

Ersumo $^{89}$ involved an Ethiopian asylum-seeker who was detained after failing, before his arrest, to obtain a permit due to queues (first) at the Pretoria RRO and (subsequently) at CTRRO. The SCA noted that, while reg 2(1) of the 2000 Regulations stipulates that an application must be submitted without delay, neither it nor the RA prescribes a time for such submission. ${ }^{90}$ The SCA ordered issuance of an asylum transit permit (which at the time was valid for 14 days), release from detention, and priority at the Port Elizabeth RRO; and, upon submission of an asylum application, the issuance of a s 22 asylum permit. ${ }^{91}$

\section{Asylum-seekers' rights and the constitutional role of dignity \\ 1 The constitutional right to dignity and its application to asylum-seekers}

Part IIB surveyed judicial responses to the Executive's attempts to curtail asylum-seekers' access to asylum procedures. This paragraph turns to its endeavour to deny asylum-seekers access to substantive rights which others, including recognised refugees, enjoy. It is contended that, rather than rely on IRL principles to compel authorities to guarantee such rights, courts have opted for utilisation of the constitutional right to dignity in s 10 of the Bill of Rights, which provides: 'Everyone has inherent dignity and the right to have their dignity respected and protected.' Yet, absent constitutional articulation of asylum-specific rights, reliance on IRL tenets would have buttressed protection claims, rendering them more resilient to prospective challenges.

Early on in its asylum jurisprudence, the Court clarified the scope of applicability of constitutional rights. In its Lawyers for Human Rights judgment, it held that they apply to 'human beings who are physically inside the country at sea or airports', given that the determination of the question whether a person is an illegal foreigner 'could adversely affect

\footnotetext{
${ }^{86}$ Ibid at para 19.

87 Bula v Minister of Home Affairs [2011] ZASCA 209, 2012 (4) SA 560 (SCA).

${ }^{88}$ Ibid at para 80.

${ }^{89}$ Ersumo v Minister of Home Affairs [2012] ZASCA 31, 2012 (4) SA 581 (SCA).

${ }^{90}$ Ibid at para 15.

91 Ibid at para 21.
} 
not only the freedom of the people concerned but also their dignity'. ${ }^{92}$ The Tsebe judgment, upholding a lower court's proscription of extradition to Botswana, emphatically stated: 'The human rights provided for in sections 10,11 and 12 of our Constitution are not reserved for only the citizens of South Africa. Every foreigner who enters our country - whether legally or illegally - enjoys these rights and the State's obligations contained in section 7(2) are not qualified in any way. ${ }^{93}$

Subsection 2 explores judgments concerning asylum-seekers' access to substantive rights; and subsection 3 addresses attempts to restrict their eligibility for less precarious legal statuses.

\section{Access to substantive rights: employment, education, and marriage}

Section 27 of the RA enumerates rights to which (recognised) refugees are entitled. Inter alia, a refugee (b) 'enjoys full legal protection, which includes the rights set out in Chapter 2 of the Constitution and the right to remain in the Republic in accordance with the provisions of this Act'. ${ }^{94}$ Refugees are also entitled to an identity document, SA travel document, and the rights to 'seek employment' and to enjoy 'the same basic health services and basic primary education which the inhabitants of the Republic receive from time to time'. ${ }^{95}$

Notably, nothing in the RA enjoins asylum-seekers qua s 22 permit holders from accessing the s 27 enumerated rights. Yet, the Executive has sought to differentiate between asylumseekers and refugees, reluctantly acknowledging the latter's statutory entitlements while denying them to the former, in respect of employment (both wage-earning and self-employment), education, medical care, and marriage. When courts extended important substantive rights to asylum-seekers, the basis for their intervention was the effect that restrictions would have on asylum-seekers' human dignity. However, had they given 'due regard' to IRL tenets, particularly the normative ramifications of the declaratory nature of refugee status, courts would have been able to rely on the 1951 Convention to bolster protection for asylum-seekers. For instance, regarding employment, art 17 of the 1951 Convention guarantees refugees 'lawfully staying' access to wage-earning employment, whereas pursuant to art 18 access to self-employment should materialise as soon as a refugee is 'lawfully' in the country. ${ }^{96}$ Regarding education, Article 22 accords to 'refugees' without temporal or others qualifications 'the same treatment as is accorded to nationals with respect to elementary education'.

Prior to the commencement of the RAA 2017, asylum-seekers' access to employment and education in SA was predicated on Watchenuka. ${ }^{97}$ The judgment concerned a Congolese widow, trained and qualified as a pharmacy technician, who entered SA from Zimbabwe with her disabled 20 year old son. Shortly after applying for asylum, she secured a place for her son to study at a Cape Town college; she sought employment to support him and herself. Alas, the Standing Committee on Refugee Affairs (SCRA) prohibited asylum-seekers and their

${ }_{92} L H R$ (note 29 above) at paras 20, 26.

${ }^{93}$ Minister of Home Affairs v Tsebe [2012] ZACC 16, 2012 (5) SA 467 (CC) at para 65. See also Tantoush (note 39 above) at para 64 (Notes the equal application of the Bill of Rights to 'foreigners' and citizens).

${ }_{94}$ RA s 27(b).

${ }^{95} \mathrm{RA} s \mathrm{2} 2$ (d), (e, (f) and (g), respectively.

961951 Convention arts 17 and 18 respectively. Part IIIE considers whether RAA 2017 provisions that explicitly restrict asylum-seekers' access to employment and education are compatible with IRL.

${ }^{97}$ Minister of Home Affairs $v$ Watchenuka [2003] ZASCA 142, 2004 (4) SA 326 (SCA). 
family members from taking up employment and from studying during the first six months of holding a s 22 permit.

While the SCA rejected SCRA's blanket prohibition policy, it accepted the premise that 'the right to enter and to remain in the Republic, and the right to choose a trade or occupation or profession, are restricted to citizens by ss 21 and 22 of the Bill of Rights'. Notably, both provisions commence with the phrase 'every citizen'; nevertheless, had the SCA employed a purposive interpretation of the provisions in light of enumerated IRL treaty rights, it could have construed such provisions as a requirement to ensure such rights to citizens, rather than as a constitutional permission to restrict access to such rights only to citizens. Under such construction, SA authorities would be required to justify exclusion of asylum-seekers from access to employment, comparing and contrasting them with other non-citizens - including recognised refugees - who enjoy such access.

The SCA opted instead to appraise the effect of destitution on human dignity, rendered by denial of employment and of access to education. For 'human dignity has no nationality. It is inherent in all people — citizens and non-citizens alike — simply because they are human. And while that person happens to be in this country - for whatever reason - it must be respected, and is protected, by section 10 of the Bill of Rights'.$^{98}$ The SCA held that the general prohibition on asylum-seekers' access to employment 'is a material invasion of human dignity that is not justifiable in terms of section 36 [of the Constitution]' given that asylum-seekers are offered no public support and thus 'a person who exercises his or her right to apply for asylum, but who is destitute, will have no alternative but to turn to crime, or to begging, or to foraging'. ${ }^{99}$ Applying a similar logic in respect of access to education, the SCA held that ' $\left.\mathrm{t}\right] \mathrm{he}$ freedom to study is also inherent in human dignity for without it a person is deprived of the potential for human fulfilment. ${ }^{100}$

Whereas Watchenuka ensured asylum-seekers' qualified access to employment ${ }^{101}$ and education $^{102}$ and as such was a key driver behind the RAA 2017 (see part III), the judgment failed to articulate rights-enhancing rationales derived from IRL obligations, relying instead on the rather vague and amorphous notions of (in)dignity and vulnerability. In turn, when the question of sector-specific restrictions on employment arose, the absence of IRL tenets in 98 Ibid at para 25.

99 Ibid at para 32.

${ }^{100}$ Ibid at para 36. See also Governing Body of the Juma Musjid Primary School \& Others $v$ Essay NO \& Others [2011] ZACC 13, 2011 (8) BCLR 761 at para 37(Holds that 'the right to a basic education in section 29(1)(a) of the Constitution is immediately realisable'). See also Centre for Child Law v Minister of Basic Education [2019] ZAECGHC 126 (12 December 2019) where the Eastern Cape High Court affirmed the right to basic education of 'undocumented' children, some born of South African parents and others of foreign nationals, noting that denial of access to school has 'devastating consequences', which 'denuded [children] of their self-esteem and self-worth, and the potential for human fulfilment' and that 'differentiating the children based on their documentation status impairs their fundamental right to dignity' which amounted to unfair discrimination prohibited by the Constitution and by the Convention on the Rights of the Child. Ibid at paras 81, 85-86.

${ }^{101}$ Also see Lucien Ntumba Musanga \& Others v Minister of Labour \& Others (NGHC, case no. 29994/18, unreported judgment)(Challenged regs $1 \& 2$ to the Unemployment Insurance Act 63 of 2001, which effectively prevented asylum-seekers from claiming Unemployment Insurance Fund benefits; the case was settled on the day of hearing, 27 February 2019, with a declaration that the impugned regulations were unconstitutional, requiring modification of the system to recognise applications submitted with asylum permit numbers).

${ }^{102}$ S Carciotto, V Gastrow, C Johnson Manufacturing Illegality? The Impact of Curtailing Asylum Seekers' Right to Work in South Africa (2017) 5(Notes that, following Watchenuka, SCRA has issued all asylum permits with the right to work and study). 
determining its constitutionality proved decisive. Union of Refugee Women ${ }^{103}$ appraised the exclusion of both asylum-seekers and recognised refugees from security service posts due to the imposition of a citizenship or permanent residence requirement. ${ }^{104}$ Rejecting the application, the Court held that the restriction had a rational purpose and that it was narrowly tailored by not applying to all industries, notwithstanding its recognition that 'refugees' are 'unquestionably a vulnerable group in our society'. ${ }^{105}$ The majority dismissed the claim that permanent residents are the relevant comparator for the purposes of appraising 'unfair discrimination' as per s 9(3) of the Constitution.

Mokgoro and O'Regan JJ, dissenting, noted that rights which 'arise from international law ... need to be understood in the light of our international obligations' and that 'preference should be given to a meaning which is consistent with our international obligations'. They posited that 'recognised refugees are most similarly situated to permanent residents' ${ }^{106}$ Yet, by focusing on recognised refugees, even the dissent implicitly accepted that sectoral restrictions may be imposed on all asylum-seekers, irrespective of the length of their stay in SA and of delays in assessing their applications, thereby refraining from critical engagement with the contours of art 17 of the 1951 Convention and its applicability in SA.

The SCA was subsequently called upon to appraise whether restrictions on self-employment are compatible with art 18 of the 1951 Convention. Limpopo ${ }^{107}$ concerned the refusal of licences and closure of spaza shops, owned and operated by refugees and asylum-seekers in Limpopo Province. The SCA held that 'if, because of circumstances, a refugee or asylumseeker is unable to obtain wage-earning employment and is on the brink of starvation, which brings with it humiliation and degradation, and that person can only sustain him- or herself by engaging in trade, ... such a person ought to be able to rely on the constitutional right to dignity in order to advance a case for the granting of a licence to trade. This is so given that South Africa has no general social assistance programme for refugees, and none of the existing grants are available to asylum seekers. ${ }^{108}$ Notably, in IRL, whereas host countries are expected to provide social assistance, ${ }^{109}$ employment rights are not derived from and are certainly not contingent on the absence of such assistance. Yet, while the SCA reprimanded 'the attitude of the State in that regard' as 'worrying and unacceptable as it would amount to defeating South Africa's international obligations arising under international refugee and human rights law', ${ }^{110}$ it did not articulate which obligations it was referring to, nor base its determination on their breach.

More recently, the SCA was handed a chance to utilise South Africa's IHRL obligations in respect of the right to marry. Mzalisi $N O^{111}$ concerned a Nigerian asylum-seeker wishing to

${ }^{103}$ Union of Refugee Women \& Others $v$ Director, Private Sector Industry Regulatory Authority \& Others [2006] ZACC 23, 2007 (4) SA 395 (CC).

${ }^{104}$ Pursuant to s 23(1)(a) of the Private Security Industry Regulation Act 56 of 2001 (but subject to an exemption in s 23(6) which, per Union of Refugee Women ibid at para 48 'if properly applied will save it from the overbreadth criticism'.).

105 Union of Refugee Women (note 103 above) at para 28.

${ }^{106}$ Ibid at paras 104, 106, 109.

${ }^{107}$ Limpopo (note 40 above).

108 Ibid at para 43.

1091951 Convention arts 20, 21, 23, and 24, referring to 'rationing', 'housing', public relief' and 'labour legislation and social security', respectively.

${ }^{110}$ Limpopo (note 40 above) at para 44.

111 Mzalisi NO \& Others $v$ Ochogwu \& Another [2019] ZASCA 138 (SCA). 
register their customary law marriage to a South African. An MHA circular proclaimed that persons 'whose asylum seeker application status is pending cannot contemplate marriage'. ${ }^{112}$ Given that neither the Marriage Act 25 of 1961 nor the Civil Union Act 17 of 2006 have immigration-related eligibility requirements, the provision was declared invalid, upholding the lower court's ruling. Yet, in so doing, the SCA judgment did not refer to art 23(2) of the ICCPR, which enunciates that ' $[t]$ he right of men and women of marriageable age to marry and to found a family shall be recognized'. Rather, the SCA turned to dignity, holding that ' $[t]$ he right to family life is not a coincidental consequence of human dignity, but rather a core ingredient of it', citing the Court's Nandutu ${ }^{113}$ judgment, which affirmed the rights of foreign spouses and children to obtain a change in visa status from within SA.

\section{Access to temporary and permanent residence permits}

While an asylum application is pending, life happens. Asylum-seekers may marry (as above). They may wish to capitalise on the greater security of permanent residence. They may seek assurance of access to rights that are haphazardly denied to $s 2$ permit holders. Hence, they may want to apply for temporary or permanent residence permits.

The dual predicament that Ahmed addressed was this: the policy of preventing asylumseeker permit-holders from applying for temporary or permanent residence permits coupled with a requirement that such applications cannot be made in-country. ${ }^{114}$ Immigration Directive 21 of 2015 issued on 3 February 2016 by the DHA Director-General stated that '[a] holder of an asylum seeker permit who has not been certified as a Refugee may not apply for a temporary residence visa or permanent residence permit." ${ }^{115}$ Hence, for instance, an asylumseeker marrying a South African would be ineligible qua asylum-seeker to apply in-country for a spousal visa. The Directive effectively qualified s 31(2) of the IA, which allows the Minister of Home Affairs to, inter alia, 'grant a foreigner the rights of permanent residence for a specified or an unspecified period when special circumstances exist which justify such a decision.' Claimants argued that, due to the backlog in the asylum system, especially in respect of Refugee Appeal Board (RAB) appeals, ${ }^{116}$ asylum-seekers are stuck indefinitely in a precarious

${ }^{112}$ Circular s 2.1(b)(iii)(dd).

${ }^{113}$ Nandutu \& Others $v$ Minister of Home Affairs \& Others [2019] ZACC 24, 2019 (8) BCLR 938 (CC) at para 1.

${ }^{114}$ Ahmed $v$ Minister of Home Affairs [2018] ZACC 39, 2019 (1) SA 1 (CC).

${ }^{115}$ Ibid at para 44 ('an official policy document, which guides government departments on how to apply legislation').

${ }^{116}$ Report of the Auditor-General on a Follow-up Performance Audit of the Immigration Process for Illegal Immigrants at the Department of Home Affairs (February 2020) at para 2.4.(d), available at http://pmg-assets.s3-website-euwest-1.amazonaws.com/200204AGSA_report.pdf (Notes that the SCRA backlog is 40326 cases and the RAB backlog is 147794 cases, which would take 68 years to attend to without taking new cases). The basis for the latter calculation is the DHA Immigration Services' Asylum Seeker Management, 2018 Annual Report, which indicated that, in 2018, the RAB issued 844 decisions, of which 600 were referred to the RSDO. According to the MHA's Written Reply to Question no. 1767 (1 June 2018), there was only one RAB panel, consisting of three members. In turn, SCRA upheld 14628 RSDO decisions in 2018; set aside 3 499; and referred 3755. The DHA Report also noted that, in 2018, 18354 arrivals had been registered as asylum-seekers, a drop from 24174 registered in 2017 and 35377 recorded in 2016. The MHA's Written Reply to Question no. 380 (26 July 2019) noted that 516 asylum-seekers with s 22 permits were waiting for an interview with an RSDO for between 30 and 90 days, whereas 2503 were waiting for an interview for more than 90 days. The average waiting time was 30 days or less. The peak years for asylum applications were 2008 and 2009, when 207206 and 223324 applications were received, respectively. Since then, application numbers have steadily lower (see MHA's Written Reply to Question no. 1766 (1 June 2018)). 
status, unable to obtain the security that other permits could offer even when their personal circumstances have changed.

The Court accepted Ahmed's appeal. It recognised that 'requiring an asylum seeker to return to their countries [sic] of origin, in order to apply, would, in all likelihood, require that the asylum seeker give up their asylum seeker permit'. ${ }^{117}$ However, given that the applicants did not challenge reg 9 (requiring applications for temporary or permanent residence permits to be made out of SA), the Court stopped short of 'unilaterally mak[ing] a provision which differentiates asylum seekers from other applicants under the Immigration Act, by directing that the Department receive these applications from asylum seekers from within the borders of the country'.

Regrettably, the Court also refrained from relying on IRL tenets to cement the normative basis underlying the claim: asylum-seekers are qualitatively different than other migrants in that, as presumptive refugees, they cannot return to their countries of origin to lodge a permit application or otherwise. Indeed, as part III illustrates below, under s 5(1)(d) of the RA (as amended by the RAA 2017), were refugees to 'visit' their country of origin for any purpose, their refugee status could be withdrawn! Denying them, as asylum-seeker permit holders, access to rights that are attached to other immigration statuses and denying them the opportunity to apply for such statuses without losing their protection cuts against the IRL logic.

The Ahmed judgment also noted that, ' $[\mathrm{t}]$ he Refugees Act protects both [refugees and asylum seekers] but their rights vary significantly'. ${ }^{118}$ The latter indeed seems to be the Executive's premise. Yet courts ought to question it: as noted above, the RA explicitly grants certain rights to 'refugees'; but if refugee status is declaratory, why should rights of asylum-seekers 'vary significantly' from those of recognised refugees?

It is argued that, ultimately, even those judgments that have protected asylum-seekers' access to rights - most notably Watchenuka, Ahmed, and Ruta - have refrained from articulating the normative significance of asylum-seekers as 'presumptive refugees' and the ensuing IRL obligations. As part III demonstrates, the RAA 2017 explicitly rejects this premise: a stark differentiation between asylum-seekers and recognised refugees lies at its core, reversing judicially mandated prescriptions from which asylum-seekers have benefited until now. The RAA 2017 also overtly diverges from the spirit and the letter of IRL instruments, yet it does not 'own' or justify the decision to do so. Indeed, perhaps inadvertently, by dovetailing the coming into force of RAA 2008, which was legislated in a more protective era, the RAA 2017's commencement has simultaneously adversely affected protection and enhanced the legal tools for prospective constitutional challenges thereto (explored in part IV).

Protracted asylum procedures may cause undue psychological distress and hinder asylum-seekers' integration. L Schockaert, E Venables, MT Gil-Bazo, G Barnwell, R Gerstenhaberk \& K Whitehouse 'Behind the Scenes of South Africa's Asylum Procedure: A Qualitative Study on Long-term Asylum-Seekers from the Democratic Republic of Congo' (2020) 39 Refugee Survey Quarterly 26.

${ }_{117}$ Ahmed (note 114 above) at para 59.

${ }^{118}$ Ibid at para 24. 


\section{THE REFUGEES AMENDMENT ACT 2017 AND INTERNATIONAL REFUGEE LAW}

\section{A The curious incident of the RAA 2017}

On 12 December 2019, President Ramaphosa signed a proclamation stipulating that the RAA 2008 'shall come into force on 1 January 2020'. ${ }^{119}$ The much-delayed commencement of the RAA $2008^{120}$ triggered an immediate coming into force of the Refugees Amendment Act 12 of 2011 (RAA 2011) and of the RAA 2017. ${ }^{121}$ The new regulations, repealing the 2000 regulations, were also gazetted and came into force on 1 January 2020.

The RAA 2008 enacts s 1A of the RA and repeals s 6 . Section 1A replicates s 6 save for one substantive change: substituting the phrase 'with due regard to' with 'in a manner that is consistent with.' As amended, the RA has to be 'interpreted and applied 'in a manner that is consistent with' the 1951 Convention, the 1967 Protocol, the 1969 OAU Convention, the Universal Declaration of Human Rights, and 'any domestic law or other relevant convention or international agreement to which the Republic is or becomes a party'. It can be argued that 'with due regard' is rather ambiguous, which perhaps partly explains why SA courts have rarely referenced it (for discussion see part II). In contradistinction, 'in a manner consistent with' is unequivocal and considerably stronger: it requires an appraisal of compatibility with the enumerated instruments in any case within the ambit of the RA.

Part IV will consider the constitutional (review) ramifications of the combined coming into effect of the RAA 2008 and the RAA 2017. ${ }^{122}$ This part explores key legislative changes brought about by the RAA 2017 affecting the livelihood of asylum-seekers in five main areas: exclusion from refugee status; access to asylum; asylum processing centres (APCs) and restrictions on movement; access to employment and education; and restrictions of political activities. Each of those changes alone, and especially taken together, represent significant backtracking from the commitment to IRL in the (unmodified) Preamble to the RA. Several changes appear to be direct responses to adverse judgments, notably Watchenuka and Limpopo (regarding access to employment and education) and Saidi (regarding asylum permits/visas). Others (re)open protection gaps which courts, utilising the Bill of Rights, sought to close.

While this article focuses on the status and rights of asylum-seekers, it would be remiss not to briefly highlight the two main detrimental effects of the RAA 2017 on status and

119 The Proclamation was published on 27 December 2019 in Government Gazette No. 42932.

${ }^{120}$ The lapse of time between legislation and implementation renders the justifiability of such measures particularly suspect. This was not the first instance in which the implementation of an Act was delayed, absent proclamation: no Presidential proclamation has ever been made under s 1(1) of the Application of Resolutions of the Security Council of the United Nations Act 172 of 1993. The (ab)use of the power to make proclamations raises interesting constitutional questions: see eg Ex Parte Minister of Safety and Security in re S $v$ Walters [2002] ZACC 6, 2002 (4) SA 613 (CC) at paras 71-73(Holds that the President's power to determine the date of coming into operation of an Act is a public power that must be exercised lawfully: it cannot be used to veto or otherwise block implementation).

${ }^{121}$ RAA 2017 s 33 stipulates that it comes into operation immediately after the commencement of the RAA 2008 and the RAA 2011; RAA 2011 s 14 stipulates that it comes into operation immediately after the commencement of the RAA 2008; RAA 2008 s 34 states that it 'comes into operation on a date determined by the President by proclamation in the Gazette'.

${ }^{122}$ RAA 2011 enacts relatively minor changes which do not fundamentally challenge IRL. For completeness, the Refugees Amendment Act 10 of 2015 came into operation on 27 September 2015, allowing the media and the public access to RAB hearings. 
rights of recognised refugees in SA and their incompatibility with the 1951 Convention. First, the legislation institutes new grounds for cessation of status (referred to as 'withdrawal'), intensifying refugee precariousness. Second, it renders permanent residence and, consequently, naturalisation, far less attainable.

Under the 1951 Convention framework, once refugee status is granted, cessation can only take place in one or more of the circumstances enumerated in the six sub-clauses of art $1 \mathrm{C}$ which 'are negative in character and are exhaustively enumerated'. ${ }^{123}$ Now, the OAU Convention's additional cessation clause (that a refugee 'has seriously infringed the purposes and objectives of this Convention') arguably raises an interpretive tension which is yet to be judicially resolved: with respect to the refugee definition, where the later, region-specific treaty is more protective, and hence should be followed by SA as party to both, under the OAU's cessation clause circumstances may arise which mandate cessation of protection but not under the 1951 Convention. ${ }^{124}$ This longstanding challenge notwithstanding, the RAA 2017 introduces new cessation clauses that are not articulated in either treaty, and revises enumerated cessation grounds in a manner that diverges from their meaning. It therefore entails withdrawal of refugee protection from persons who should continue to enjoy it under both the 1951 Convention and the OAU Convention. ${ }^{125}$ Four RAA 2017 stipulations are particularly concerning.

First, the Minister of Home Affairs is authorised to 'cease the recognition of the refugee status of any individual refugee or category of refugees, or to revoke such status'. ${ }^{126}$ Whereas s 5(1)(e) of the RA has already provided for cessation of status where a change of circumstances related to the grounds for recognition had occurred (as per arts 1C(5-6) of the 1951 Convention), the new cessation ground provides no guidance as to the additional basis for a decision to cease status of individuals or indeed en masse.

Second, the RAA authorises cessation of status if a refugee merely 'returns to visit' that country. ${ }^{127}$ Section 5(1)(d) of the RA pre-RAA 2017 followed the 1951 Convention art 1C(4) stipulation that a refugee must have 'voluntarily re-established' themselves in the country which they left to meet that cessation ground. UHNCR's longstanding position is that 'refugees

${ }^{123}$ UNHCR Handbook on Procedures (note 39 above) para 116. See also S Kneebone \& Maria O'Sullivan 'Article 1C' in A Zimmermann (ed) The 1951 Convention relating to the Status of Refugees and its 1967 Protocol: A Commentary (OUP 2011) 480, 483; G Cole 'Cessation Clauses' in Oxford Handbook of International Refugee Law (note 27 above).

${ }^{124}$ Compare International Law Commission (ILC), Fragmentation of International Law: Difficulties arising from the Diversification and Expansion of International Law, Conclusions of the Work of the Study Group, UN doc A/ CN.4/L.702 (18 July 2006) (the question here is one of conflict between norms governing the same area of treaty law).

${ }^{125}$ There is also no apparent regional practice that potentially alters the scope of IRL in the African region. For discussion see DJ Cantor \& F Chikwanha 'Reconsidering African Refugee Law' (2019) 31(2-3) International Journal of Refugee Law 182. Cantor \& Chikwanha also call for a 'broader consideration of whether national refugee laws provide evidence of wider processes of custom formation in relation to other rules, particularly those that fall outside the terms of existing refugee treaties'. 'Reconsidering African Refugee Law' fn 378 page 245

${ }^{126} \mathrm{RA}$ (as amended) s 5(1)(h).

${ }^{127}$ RA (as amended) s 5(1)(d). For example, see R Ziegler Voting Rights of Refugees (2017) ch 6 (re challenges arising in respect of refugee Out-of-Country Voting, including risk of premature cessation, as per arts $1 \mathrm{C}(1),(5)$ of the 1951 Convention). 
should be able to make visits 'to their country of origin to inform themselves of the situation there - without such visits automatically involving loss of refugee status'. ${ }^{128}$

Third, the new regulations consider engagement with the country of origin's consular authorities without prior permission of the Minister as a basis for withdrawal of refugee status - an unduly expansive interpretation of the art 1C(1) 're-availment' of 'protection' clause. Moreover, this is a rather remarkable stipulation given that $S A$ authorities often require refugees to provide birth or marriage certificates, which can only be issued to refugees by their country of nationality. ${ }^{129}$ Elsewhere, ${ }^{130}$ I cautioned against host countries' reliance on contacts with country of origin officials to consider refugees as having 're-availed' themselves of the 'protection' of their country, even though many refugees may fear the actions of non-state actors in their country of origin rather than state officials. Nevertheless, an explicit blanket legislative stipulation to that effect is a radical departure from global practice.

Fourth, and somewhat relatedly, the new regulations pronounce that any person who 'stands for political office or votes in any election ... of ... country of nationality without the approval of the Minister' ${ }^{\prime 31}$ or 'participates in any political campaign or activity related to ... country of origin or nationality whilst in the Republic without the permission of the Minister ${ }^{132}$ will have their refugee status withdrawn. Elsewhere, ${ }^{133}$ I warned against the possibility that host countries would consider participation in country of origin elections as ground for cessation, especially when done in-country but even when refugees vote remotely. The new stipulation goes much further, with the pre-authorisation requirement likely to have a chilling effect on refugees seeking to protest abuses in their country of origin including those which may have caused their flight. ${ }^{134}$

By design, the RAA 2017 severs any ties that may remain between refugees and the political communities of their country of origin. It is therefore particularly unwelcome that it concomitantly doubles, from five to ten years, the residence requirement that must be satisfied before a recognised refugee can apply to have their status certified, a precursor to grant of permanent residence, which in turn is a precursor to naturalisation. ${ }^{135}$ This retrogressive approach is at odds with IRL: while art 34 of the 1951 Convention does not require naturalisation of refugees, asylum countries undertake to 'as far as possible... facilitate the[ir] assimilation and naturalization' and, at the very least, should certainly not be rendering naturalisation for refugees harder than for other migrants. ${ }^{136}$

${ }^{128}$ UNHCR ExCom Conclusion No. 18 (Voluntary Repatriation) (16 October 1980) para (e), available at https:// www.unhcr.org/uk/excom/exconc/3ae68c6e8/voluntary-repatriation.html.

${ }^{129}$ Regulations 4(1)(a-d) of the new Regulations.

${ }^{130}$ Ziegler Voting Rights of Refugees (note 127 above) ch 7.

${ }^{131}$ Regulation 4(1)(g) of the new Regulations.

${ }^{132}$ Regulation 4(1)(i)) of the new Regulations.

${ }^{133}$ Ziegler Voting Rights of Refugees (note 127 above) ch 6.

${ }^{134}$ For discussion of permissible modes of political participation pre RAA 2017, see M Mpeiwa 'The Case of Congolese Refugees in South Africa' in L Antara (ed) Political Participation of Refugees (2018).

${ }^{135}$ Section 27(3) of the RA (as amended). Further to doubling the post-recognition residence period, the amended provision also mandates SCRA to consider 'all the relevant factors and within a reasonable period of time, including efforts made to secure peace and stability in the refugee's country of origin' before it 'certifies' that the applicant 'would remain a refugee indefinitely'.

${ }^{136}$ For discussion see F Khan and R Ziegler 'Refugee Naturalization and Integration: Where "Durable Solutions" meet Socio-Political Realities' in Oxford Handbook of International Refugee Law (note 27 above). 
In addition to the new restrictions on recognised refugees, part $\mathrm{F}$ appraises new prohibitions on political activities of asylum-seekers within South Africa. Consequently, recognised refugees are now restricted in their political engagement vis-à-vis their country of origin, on pain of cessation/withdrawal of status; prohibited from taking part in political activities related to SA; and have vanishingly small prospects of naturalising and consequently enjoying full membership of SA's political community, including electoral participation.

In Voting Rights of Refugees, ${ }^{137}$ I argue that recognised refugees are a special category of non-citizen residents in need of (full) membership in a political community for an indeterminate, ex ante unknown, period of time; and that it is therefore desirable, de lege ferenda, that they be treated by their countries of asylum as if they were their citizens in respect of entitlements which, in international law, may be subject to a citizenship qualification including electoral rights. Post- RAA 2017, South Africa offers an illustration of the political limbo in which refugees may find themselves in their countries of asylum. In Arendt's terms, recognised refugees in SA are now deprived of 'a place in the world which makes opinions significant and actions effective'. ${ }^{138}$

\section{B Exclusion from refugee status}

Article 1F of the 1951 Convention defines three categories of persons to whom the 1951 Convention shall not apply due to the deplorable nature of acts that they have committed prior to admission to a country of asylum. Such exclusions pertain to underserving persons. In turn, Article $1 \mathrm{E}$ denies the application of 1951 Convention protections to a person 'recognized by the competent authorities of the country in which he has taken residence as having the rights and obligations which are attached to the possession of the nationality of that country'. Article $1 \mathrm{E}$ exclusions thus apply to those deemed to enjoy elsewhere status superior to that of refugees.

RAA 2017 amends s 4(1)(d) of the RA to exclude any person who 'enjoys the protection of any other country in which he or she is a recognised refugee, resident or citizen' (emphasis added), adding 'resident' to the original RA articulation. The UNHCR Handbook on Procedures posits that 'the [art 1E] exclusion operates if a person's status is largely assimilated to that of a national of the country. In particular he must, like a national, be fully protected against deportation or expulsion. ${ }^{139}$ Yet residence (unlike permanent residence) does not generally offer such protection. In amending s 4(1)(d), the RAA 2017 is effectively following the White Paper in adopting a 'safe first country of entry' approach ${ }^{140}$ which substantively diverges from the emphasis put in Article $1 \mathrm{E}$ of the 1951 Convention on security of residence in a non-persecutory country as per its nationals being sine qua non for its application. ${ }^{141}$

\footnotetext{
${ }^{137}$ Ziegler Voting Rights of Refugees (note 127 above) ch 8.

${ }^{138} \mathrm{H}$ Arendt The Origins of Totalitarianism (1950) 296.

${ }^{139}$ UNHCR Handbook on Procedures (note 39 above) at para 145.

${ }^{140}$ DHA White Paper on Home Affairs (August 2019) (noting that 'asylum seekers should seek refuge in the first safe country they enter'), available at http://www.dha.gov.za/images/PDFs/UPDATEDdhawhitepaper2019.pdf. Compare re transfer agreements: S Bar-Tuvia 'Australian and Israeli Agreements for the Permanent Transfer of Refugees: Stretching Further the (Il)legality and (Im)morality of Western Externalisation Policies' (2018) 30(3) International Journal of Refugee Law 477.

${ }^{141}$ Article $1 \mathrm{E}$ of the 1951 Convention excludes a person 'recognized by the competent authorities of the country in which he has taken residence as having the rights and obligations which are attached to the possession of the nationality of that country.'
} 
Within the 1951 Convention framework, the three art $1 \mathrm{~F}$ exclusion clauses constitute an exhaustive list and, given their effect, must 'always be interpreted in a restrictive manner'. ${ }^{142}$ In Africa, the OAU Convention's additional exclusion clause, that a person 'has been guilty of acts contrary to the purposes and principles of the Organization of African Unity' ${ }^{143}$ raises similar interpretive questions to those discussed above regarding the additional clause concerning cessation of status. Sections 4(1)(a) (b), and (c) of the (pre-RAA 2017) RA include 'exclusion' clauses which broadly reproduce arts $1 \mathrm{~F}(\mathrm{a})$, (b), and (c) of the 1951 Convention, the latter relating to acts against the 'objects' (akin to purposes) and 'principles' of both the UN Charter and the OAU Convention. Yet, similarly to its approach to cessation, the RAA 2017 introduces five new exclusion clauses which are not recognised by either the 1951 Convention or the OAU Convention. The effect of each of the five new clauses is to deny refugee status to persons who are 'refugees' within the meaning of art $1 \mathrm{~A}(2)$ of the 1951 Convention and the OAU Convention. Taken together, they have profound effects on the scope of refugee protection in SA. ${ }^{144}$

Given that unamended s 2 of the RA still protects excluded individuals from being deported or expelled to a country where they would be exposed to the risks stipulated in $s 3$, such persons could be left in indefinite legal limbo: no permit/visa either under the RA or the IA could be issued to regularise their sojourn in SA, so they would be protected from refoulement whilst left undocumented and subject to harassment, arrest, or indeterminate detention.

The new exclusion clauses are appraised below.

1 New section 4(1)(e): "has committed a crime in the Republic which is listed in Schedule 2 of the Criminal Law Amendment Act, 1997 (Act No. 105 of 1997), or which is punishable by imprisonment without the option of a fine'

Gavric concerned the application of pre RAA 2017 s 4(1)(b) of the RA, pertaining to exclusion of persons who committed a crime 'which is not of a political nature'. ${ }^{145}$ The provision resembled art $1 \mathrm{~F}(\mathrm{~b})$ of the 1951 Convention, the application of which is explicitly limited to 'serious non-political' crimes committed outside the country of refuge prior to admission to that country as a refugee. In contrast, individuals who commit a crime in the country of refuge should be subject to that country's criminal law process. ${ }^{146}$ This, as the SCA noted in

${ }_{142}$ UNHCR Guidelines on International Protection No. 5: Application of the Exclusion Clauses: Article $1 F$ of the 1951 Convention relating to the Status of Refugees HCP/GIP/03/05 (4 September 2003) at paras 2-3.

${ }^{143}$ The OAU'S 'purposes' and 'principles' are outlined in the Charter of the Organization of African Unity, 25 May 1963, 479 United Nations Treaty Series 39, arts II \& III. They bear considerable overlap with the purposes and principles of the UN in arts II \& III of its Charter - which form the third ground for exclusion from status under Art 1F of the 1951 Convention.

${ }^{144}$ Cantor \& Chikwanha (note 125 above) fn 252 (Notes that, other than SA, only seven countries out of 46 African countries surveyed have added exclusion clauses to the enumerated list in the OAU Convention. Other than SA, only Tanzania and Zimbabwe exclude persons granted refugee status by another country — both exempting persons who arrive via a territory 'where there has been a serious breach of peace'. Ibid fn 260).

${ }_{145}$ Gavric v Refugee Status Determination Officer [2018] ZACC 38, 2019 (1) SA 21 (CC) at para 50(Considers an exclusion decision to be a substantive decision like a decision by an RSDO to reject an application which triggers review by SCRA, for manifestly unfounded, fraudulent and abusive applications, or an appeal to RAB for unfounded applications).

${ }^{146}$ UNHCR Guidelines on International Protection (note 142 above) at paras 5, 16. 
Ruta, is due to the exceptional nature of the exclusion provisions and the severe consequences of exclusion for an individual. ${ }^{147}$

The RAA 2017 amends s 4(1)(b) of the RA to add the words 'outside the Republic', clarifying that provision's application to the circumstances anticipated in art $1 \mathrm{~F}(\mathrm{~b})$. But it also adds a new provision, subsection (e), excluding from status any person who committed a crime in the Republic, which is listed in Schedule 2 of the Criminal Law Amendment Act 105 of 1997), or which is punishable by imprisonment without the option of a fine. The modification of s 4(1)(b) magnifies the breach of IRL that is manifested by subsection (e): the 1951 Convention requires host countries to deal with criminal activities committed within their territories through their criminal law, rather than through exclusion from status. This is illustrated by the fact that host countries are permitted — under stringent conditions and subject to nonrefoulement - to expel refugees on grounds of 'national security or public order' (art 32 of the 1951 Convention). Adding insult to injury, it is not clear that Schedule 2 offences meet the 'serious non-political crime' test that would have to apply to offences committed outside SA. Indeed, it is even questionable whether the pre-amendment criterion ('offence punishable by imprisonment without the option of a fine') satisfies this standard.

In addition to the new exclusion ground, a similar provision was introduced as a new cessation ground, raising similar concerns. ${ }^{148}$

\section{New section $4(1)(f)$ : has committed an offence in relation to the fraudulent possession, acquisition or presentation of a South African identity card, passport, travel document, temporary residence visa or permanent residence permit}

Article 31 of the 1951 Convention, entitled 'refugees unlawfully in the country of refuge', recognises that, asylum-seekers are often forced to arrive at or enter a territory without prior authorisation. They may differ fundamentally from other migrants in that they may not be able to comply with the legal formalities for entry. For instance, they may not be able to obtain the necessary documentation in advance of their flight because of their fear of persecution and/or the urgency of their departure. The Court in Saidi noted that '[s] uch is their [refugees'] desperation that they almost all enter the country where they seek refuge illegally and without any official documents' ${ }^{149}$ Signatories to the 1951 Convention therefore undertake in subsection (1) not to impose penalties for their 'illegal entry or presence' on 'refugees' who are 'coming directly from a territory where their life or freedom was threatened' provided they 'present themselves without delay to the authorities' and 'show good cause for their illegal entry or presence'. ${ }^{150}$

${ }^{147}$ Ruta SCA (note 36 above) at para 65.

${ }^{148}$ RA (as amended) s 5(1)(f).

149 Saidi (note 79 above) at para 71 . Notably, under art 27 of the 1951 Convention, SA is required to issue identity papers to 'any refugee in their territory who does not possess a valid travel document'.

150 The prevailing interpretation of art 31(1) is that its protections apply to persons who have briefly transited through other countries or who are unable to find effective protection in the first country or countries to which they flee; and that the requirement to present oneself 'without delay' must not be interpreted as a strict temporal requirement but rather depend on the refugee's understanding of which authority they should report to and the availability of that authority. As for 'good cause', having a well-founded fear of persecution is in itself good cause for illegal entry. For broader discussion see e.g. G Noll 'Article 31' in A Zimmerman (note 123 above) ch 50; C Costello, Y Ioffe \& T Büchsel Article 31 of the 1951 Convention Relating to the Status of Refugees (2017). 
Exclusion from refugee status, as per new subsection (f), due to fraudulent 'possession, acquisition or presentation' of an official document - assuming such document was used to secure entry into SA in order to seek asylum - constitutes wholesale denial of refugee protection to those who meet the 1951 Convention definition for actions they have undertaken for which they should not be penalised. The non-penalisation rationale stems from the declaratory nature of refugee status: lacking safe and legal routes to asylum in a host country, 1951 Convention refugees should not be penalised merely for seeking to obtain it by irregular means.

Again, a similar provision was introduced as a new cessation ground, raising similar challenges. ${ }^{151}$

\section{New section 4(1)(g): fugitives from justice in another country where the 'rule of law is upheld by a recognisable judiciary'}

New exclusion subsection (g) raises both conceptual and practical challenges. The 1951 Convention 'refugee' definition, which the RA incorporated, refers to a person who has a well-founded fear of persecution for one or more of the five 1951 Convention reasons, including 'membership of a particular social group'. There are many refugee-producing countries where a 'recognisable judiciary' (undefined term) is applying laws in other countries that are, for instance, persecutory towards LGBT+ persons. ${ }^{152}$ Article 1 (xxi) of the RA defines 'social group' to include 'among others, a group of persons of particular gender, sexual orientation, disability, class or caste'. The new provision could force the designation by South Africa of all countries where LGBT+ persons are persecuted as either not having a 'recognisable judiciary' or as countries where 'the rule of law is [not] upheld'. Otherwise, it would undermine the fundamental premise of the RA by excluding persons fleeing such countries who are clearly in need of protection.

4 New section 4(1)(h): having entered the Republic other than through a designated Ports Of Entry fails to satisfy an RSDO that there are compelling reasons for doing so

In addition to applying to those arriving or securing entry through the use of false or falsified documents, the non-penalisation requirement in art 31 of the 1951 Convention also applies to those entering the country clandestinely. ${ }^{153}$ As per Asfaw, the purpose is 'to protect refugees from the imposition of criminal penalties for breaches of the law reasonably or necessarily committed in the course of flight from persecution or threatened persecution'. ${ }^{154}$ Now, exclusion under the new provision can supposedly be avoided, provided that 'compelling reasons' are offered; yet such reasons are neither listed in the RAA 2017 nor in the new Regulations, leaving it to the RSDO's discretion. ${ }^{155}$ The principled objection to exclusion as

${ }^{151}$ RA (as amended) s 5(1)(g).

${ }^{152}$ Re criminalisation, see https://www.humandignitytrust.org/lgbt-the-law/map-of-criminalisation/.

${ }^{153}$ GS Goodwin-Gill 'Article 31 of the 1951 Convention Relating to the Status of Refugees: Non-Penalization, Detention, and Protection' in E Feller, V Türk, F Nicholson (eds) Refugee Protection in International Law: UNHCR's Global Consultations on International Protection (2003) 186, 196; see also Ex parte Adimi (note 46 above).

${ }^{154} R v$ Asfaw (UNHCR Intervening) [2008] $1 \mathrm{AC} 1061$ (Bingham LJ) at para 9.

${ }^{155}$ Irrespective of other grounds for constitutional review discussed in part IV, this broad and undefined discretion would likely be found to be unconstitutional, based on the Dawood ratio. See Lawyers for Human Rights $v$ Ministry of Home Affairs and Others [2017] ZACC 22, 2017 (5) SA 480 (CC) at paras 49-50. 
a form of penalisation for breach of immigration law, articulated in the above discussion of s $4(\mathrm{f})$, applies here too.

Asylum-seekers arriving at a PoE, declaring their intent to apply for asylum, should receive an Asylum Transit Visa (ATV), issued pursuant to s 23 of the IA, for a period of five days (as per the 2011 IAA, which reduced its length from the previous 14 days). For persons entering not through a PoE and hence lacking an ATV, or who have not been issued an ATV, the new regulations effectively deny any opportunity to apply for asylum unless they are either permanent residents or citizens of a neighbouring country and can show 'good cause' for their 'illegal entry'. ${ }^{156}$ The new regulations appear to conflate penalisation for illegal entry of persons who fail to meet the 1951 Convention art 31 tests, which is permissible, with their exclusion from protection, which is not.

5 New section 4(1)(i): has failed to report to the RRO within five days of entry into the Republic ... in the absence of compelling reasons which may include hospitalisation, institutionalisation, on any other compelling reason provided that this provision shall not apply to a person who, while being in the Republic on a valid visa, other than a visa issued in terms of section 23 of the Immigration Act, applies for asylum

The ATV regime, described above, raises serious procedural concerns. Asylum-seekers must travel considerable distances to reach an RRO. When RROs devote only one day per week to applications of certain nationalities, the temporal limitation makes it more likely that irregular entry and non-reporting would render them undocumented. ${ }^{157}$ The new subsection (i) entails that, by missing an extremely narrow application window, presumptive refugees who have received an ATV upon entry will be excluded from status.

The new regulations refer to a 'valid' ATV as a pre-condition for an asylum application, unless a person is a 'permanent resident or a citizen of a neighbouring country': the reference to 'compelling reasons' in subsection (i) is not repeated in the new regulations. Recognising the category of refugees sur place, that is persons who have entered SA on a different visa and whose protection needs have arisen since, the new regulations nevertheless do not stipulate how such applications can be submitted - a challenge, given that an application must include a 'proof of declaration of the intention to apply for asylum in the form of an ATV. ${ }^{158}$

\section{Access to asylum and abandonment of applications}

Section 22(1) of the RA (as amended) stipulates that 'an asylum seeker whose application in terms of s 21(1) has not been adjudicated, is entitled to be issued with an asylum seeker visa, in the prescribed form, allowing the applicant to sojourn in the Republic temporarily, subject to such conditions as may be imposed, which are not in conflict with the Constitution or international law' (emphasis added). The rhetorical commitment to avoid conflict with the Constitution or with 'international law' hits the provision's substantive brick wall for two reasons. The first is the retrogressive denial of asylum-seekers' access to employment and education (paragraph IIIE below). The second is the authorised withdrawal of visas in circumstances which Saidi

\footnotetext{
${ }^{156} \operatorname{Reg} 8(1)(c)(i)$ of the new Regulations.

${ }^{157}$ F Khan \& M Lee 'Policy Shifts in the Asylum Process in South Africa Resulting in Hidden Refugees and Asylum Seekers' (August 2018) 4(2) African Human Mobility Review 1205.

${ }^{158}$ Regulation 8(1)(c)(i) of the new Regulations.
} 
held to be unconstitutional: s 22(5) authorises the Director-General 'at any time prior to the expiry of an asylum seeker visa' to 'withdraw such visa ... if (b) 'the application for asylum has been found to be manifestly unfounded, abusive or fraudulent' (c) 'the application for asylum has been rejected'. ${ }^{159}$ In turn, the Director-General can, 'subject to section 29 , cause the holder [of a withdrawn asylum seeker visa] to be arrested and detained pending the finalisation of the application for asylum, in the manner and place determined by him or her with due regard to human dignity'. ${ }^{160}$ Taken together, an asylum-seeker visa may be withdrawn despite an application for asylum awaiting final determination by the SCRA, the RAB, or pending judicial review. ${ }^{161}$

The RAA 2017 introduces the notion that an asylum application becomes abandoned one month after the expiry of an applicant's visa, ${ }^{162}$ unless the applicant proves to SCRA that he or she was either institutionalised, entered into a Witness Protection Programme, was quarantined, or was arrested without bail. ${ }^{163}$ At the time of writing, the new provision will adversely impact persons particularly in the Western Cape due to the failure to properly implement the Scalabrini (II) court order (reopening the CTRRO) and the Nbaya court order (renewing permits originally issued in another RRO). ${ }^{164}$

In turn, any asylum-seeker who is found to have abandoned his/her application will not be allowed to reapply and will be dealt with by an immigration officer in terms of the provisions of the IA. ${ }^{165}$ Given that the provision clearly applies to those whose applications are pending, ${ }^{166}$ the consequences are dire: should an asylum-seeker fail for any other reason to travel to a far-away RRO at regular intervals to renew their visa, they will be classified as an 'illegal foreigner' under the IA, and face risk of refoulement (only to be trumped by s 2 of the RA). Back to square one, then.

159 Other grounds for withdrawal: (a) the applicant contravenes any condition endorsed on that visa; (d) the applicant is or becomes ineligible for asylum in terms of $s 4$ (exclusion) or $s 5$ (cessation).

${ }^{160} \mathrm{RA}$ (as amended) s 23.

${ }^{161}$ See Reply to Question NW1292 to the Minister of Home Affairs (22 November 2019), available at https://pmg. org.za/committee-question/12750/(Notes that, in 2018, 3706 High Court review applications were registered; the equivalent 2017 figure is 2493). See also Reply to Question NW1970 to the Minister of Home Affairs (27 June 2018), available at https://pmg.org.za/committee-question/9306/(Notes that, in the years 2013-2018, there were 5288 judicial reviews).

${ }^{162}$ RA (as amended) s 22(12). As per s 22(13), an applicant whose application was abandoned cannot re-apply and must be dealt with as an illegal foreigner in terms of s 32 of the IA

${ }^{163}$ The permissible conditions are stipulated in reg 11(10) of the new Regulations, yet it is not clear how an asylumseeker is to present their case before SCRA.

${ }^{164}$ Scalabrini v Minister of Home Affairs (submitted 24 March 2020) (WCHC) (papers with author) (challenging ss 22(12), (13) and reg 9 of the new Regulations).

${ }^{165}$ RA (as amended) s 22(1); reg 9(3) of the new Regulations.

${ }^{166}$ Additionally, asylum appeals must be lodges within ten working days, absent institutionalisation, entry into a witness protection programme, quarantine or arrest without bail. Regulation 14(1) of the new Regulations. 


\section{Asylum processing centres and restrictions on movement}

The pre-RAA 2017 RA opted for a non-encampment policy, ${ }^{167}$ paving the way for local integration of asylum-seekers and refugees. ${ }^{168}$ The RAA 2017 arguably reverses this policy objective in respect of asylum-seekers by authorising the DHA Director-General to 'require any category of asylum seeker to report to any particular or designated RRO, or other place specially designated as such, when lodging an application for asylum' (emphasis added). ${ }^{169}$ It further stipulates that such designation may be made for specific countries of origin, geographical area, gender, nationality, political opinion, or social group. ${ }^{170}$ Article 3 of the 1951 Convention stipulates that the treaty shall apply to refugees 'without discrimination as to race, religion, or country of origin': discrimination between asylum-seekers based on county of origin would arguably prima facie breach IRL.

The Minister of Home Affairs (MHA) 2017 White Paper revealed that SA is planning to build APCs near its borders with Zimbabwe and Mozambique 'that will be used to profile and accommodate asylum seekers during their status determination process' ${ }^{.71}$ It anticipates that governmental departments and international organisations (including UNHCR and the ICRC) will operate there. The Paper proposes that 'low risk' (a term that it does not define) asylum-seekers may have the right to enter or leave the facility and be released into the care of national or international organisations and family or community members, who would have to provide assurances that basic services will be provided for. ${ }^{172}$

The new regulations do not specify a time limit for enforced presence at the APCs. Meanwhile, they remove the time limits set in s 3(1) of the 2000 Regulations, which stipulated that an asylum claim will generally be 'adjudicated' within 180 days and that the first interview will take place within 30 days; and which set in place procedures to follow when applications remain in process after 180 days. Concomitantly, asylum-seekers will be deprived of the Watchenuka and Limpopo court-mandated access to employment and education, respectively (see part IIIE below) 'since their basic needs will be catered for in the processing centres'. APCs may not be called detention centres, but their proposed modus operandi conforms. ${ }^{173}$ Indeed, as UNHCR argues, the key questions are whether an asylum-seeker is de facto deprived of their

${ }^{167}$ J Crush, C Skinner, M Stugaitis 'Benign Neglect or Active Destruction? A Critical Analysis of Refugee and Informal Sector Policy and practice in South Africa' (2017) 3(2) African Human Mobility Review 751, 753. Note RA s 35 (reception and accommodation of asylum seekers in event of mass influx) which permits the MHA (2) 'after consultation with the UNHCR representative and the Premier of the province concerned [to] designate areas, centres or places for the temporary reception and accommodation of asylum-seekers or refugees...' This subsection was never activated. Regarding practices elsewhere in Africa $c f$ Maple (note 72 above) App 1: Table 5 ('Countries with Long Term Encampment Policies and FOM Restrictions in National Legislation').

${ }^{168}$ Hence, courts have not had to reconcile s 21(1) of the Bill of Rights, proclaiming that 'everyone has the right to freedom of movement' with s 21(3) thereof, which guarantees 'every citizen...the right to enter, to remain in and to reside anywhere in the Republic' (emphases added).

${ }^{169}$ RA (as amended) s 21(c).

${ }^{170}$ RA s 21 (d).

171 White Paper on International Migration (note 13 above) 61.

${ }^{172}$ Ibid.

${ }^{173}$ Compare R Ziegler 'No Asylum for "Infiltrators": The Legal Predicament of Eritrean and Sudanese Nationals in Israel' (2015) 29(2) Journal of Immigration, Asylum and Nationality Law 172 (Appraises an Israeli High Court of Justice judgment quashing legislation that mandated the holding of persons in 'residence centres'). 
liberty (regardless of labels) and whether such deprivation is lawful according to international law. ${ }^{174}$

Asylum-seekers enjoy protection with respect to detention under both IRL and IHRL. ${ }^{175}$ The ICCPR stipulates that 'everyone has the right to liberty and security of person', and that 'no one shall be subjected to arbitrary arrest or detention'. The Human Rights Committee (HRC) opined that restrictions pursuant to art 9 can be direct or indirect: for instance, providing a person with the necessities of life in only a specified location amounts to a restriction on freedom of movement and choice of residence. ${ }^{176}$ It accepted that 'an asylum seeker may be detained for a brief initial period in order to document their entry, record their claims and determine their identity if it is in doubt. To detain them further while their claims are being resolved would be arbitrary in the absence of reasons specific to the individual, such as an individualized likelihood of absconding, a danger of crimes against others, or a risk of acts against national security. ${ }^{177}$ The HRC further noted that detention 'must ... not be based on a mandatory rule for a broad category, must take into account less invasive means of achieving the same ends, such as reporting obligations, sureties or other conditions to prevent absconding, and must be subject to periodic re-evaluation and judicial review'. ${ }^{178}$ Hence, in order for restrictions of liberty of asylum-seekers to be lawful under the ICCPR, they must include substantive and procedural safeguards; the RAA 2017 clearly lacks both. ${ }^{179}$

In turn, the IRL treaty basis for restrictions on movement of asylum-seekers rests in art 31(2) of the 1951 Convention, which enjoins host countries from 'apply[ing] to the movements of such refugees restrictions other than those which are necessary and such restrictions shall only be applied until their status in the country is regularized or they obtain admission into another country'. The 'necessity' test under art 31(2) is coterminous with the prohibition on 'arbitrary' detention in art 9 of the ICCPR, above. As for 'regularization', the better view is that its meaning is confined to lifting the unlawfulness of the illegal entry or presence of the refugee concerned, exchanging the unauthorised presence for an authorised one (in SA, arguably that translates to the issuance of a s 22 visa to an asylum-seeker), rather than a completed refugee

${ }^{174}$ UNHCR Guidelines on the Applicable Criteria and Standards relating to the Detention of Asylum-Seekers and Alternatives to Detention (2012), available at https://www.unhcr.org/publications/legal/505b10ee9/ unhcr-detention-guidelines.html. Compare HCJ 8425/13 Eitan et al v Israeli government et al (22 September 2014) (Israeli Supreme Court)(Holds that the Holot 'residence centre' was a de facto detention centre and hence that the 2013 Law for the Prevention of Infiltration (Amendment no. 4) violated the constitutional rights to liberty and human dignity. For analysis see RR Ziegler 'No Asylum for "Infiltrators": The Legal Predicament of Eritrean and Sudanese Nationals in Israel' (2015) 29(2) Journal of Immigration, Asylum and Nationality Law 172.

${ }^{175}$ For discussion see M Zieck 'Refugees and the Right to Freedom of Movement: From Flight to Return' (2018) 39(1) Michigan Journal of International Law 196 (comparing art 9(1) of the ICCPR with art 31(2) of the 1951 Convention).

${ }^{176}$ HRC General Comment No. 35: Article 9 (Liberty and Security of Person) (16 December 2014) at para 20.

177 Ibid at para 18.

${ }^{178}$ Ibid.

${ }^{179}$ Compare UN Working Group on Arbitrary Detention report regarding 'transit zones' set by Hungary on the Hungarian-Serbian border, noting that 'there can be no doubt that holding migrants in these "transit zones" constitutes deprivation of liberty in accordance with international law' (15 November 2018), available at https://bit.ly/2B7X5Pu; but see the European Court of Human Rights' Grand Chamber judgment in App No. 47287/15 Ilias and Ahmed v Hungary (21 November 2019), holding by a majority (Bianku, Vucinic JJ dissenting) that despite 'significant restriction on their freedom of movement, [the restrictions] did not limit their liberty unnecessarily or to an extent or in a manner unconnected to the examination of their asylum claim', in part due to the fact that, as stated at para 242 , 'the applicants spent only twenty-three days in the zone'. 
status determination procedure. ${ }^{180}$ Once regularisation occurs, asylum-seekers should enjoy the protection of art 26 of the 1951 Convention, which requires a country of asylum to 'accord to refugees lawfully in its territory the right to choose their place of residence to move freely within its territory, subject to any regulations applicable to aliens generally in the same circumstances. ${ }^{181}$

In October 2018, the Committee on Economic, Social, and Cultural Rights (CESCR) expressed concerns about 'the proposal of establishment of asylum processing centres in border areas' as well as 'the reportedly large backlog of asylum applications pending in the appeal process' 182 and urged South Africa to '[e]xpeditiously clear the backlog of asylum applications pending in the appeal process'. ${ }^{183}$ At the time of writing, no APC has been built, while the backlog remains.

\section{E Access to employment and education}

Part II demonstrated how courts have steadily chipped away at government policies attempting to restrict access of asylum-seekers to wage-earning employment, self-employment, and education, as well as sought to restrict their movement. The Green Paper on Immigration, which preceded the RAA 2017, posited that 'the adoption of a policy of non-encampment that, coupled with non-provision of basic food and accommodation to "indigent asylum-seekers" has led courts to 'oblig[ing] the Department of Home Affairs to consider issuing deserving cases with permits allowing them to work or study' which 'has become a powerful "pull factor" which further burdens the asylum system leading to many adjudication cases being delayed for years'. ${ }^{184}$ The government's assessment therefore recognises that, judicially sanctioned access to employment came about first and foremost because asylum-seekers do not receive social assistance while their applications are appraised. The RAA 2017 'responds' to the challenge both by paving the way for confining asylum-seekers to APCs (as per above) and by reversing the post Watchenuka and Limpopo default regarding asylum-seekers' access to wage-earning employment, self-employment, and education. ${ }^{185}$

Under the RAA 2017, asylum-seekers wishing to have their right to work 'endorsed' on their visa $^{186}$ must satisfy an RSDO that they are unable to sustain themselves and their dependants. ${ }^{187}$ They 'may be assessed' (pursuant to undefined parameters) to determine their eligibility. ${ }^{188}$ Should they be successful in demonstrating that they cannot self-sustain, 'they may be offered

${ }^{180}$ HRC General Comment (note 176 above) at para 18.

${ }^{181}$ In Scalabrini (II) (note 69 above), the SCA regarded restrictions on access to RROs (caused by the closure of the Cape Town RRO) as having an adverse effect on the right of 'refugees lawfully in its territory' to 'choose their place of residence and move freely within the asylum country's territory' (but has not pronounced on IRL ramifications).

${ }^{182}$ ICESCR Concluding Observations on the Initial Report of South Africa (12 October 2018) at para 25.

${ }^{183}$ Ibid at para 26(a).

${ }^{184}$ Green Paper (note 12 above) at para 12.

${ }^{185}$ Reacting to the Green Paper, UNHCR noted that 'the right to work is a fundamental human right, integral to human dignity and self-respect, and that reliance on assistance is not conducive to self-sufficiency'. B Jordan 'Not in our name, UN body tells SA', Sunday Times, 12 March 2017, available at https://www.pressreader.com/ south-africa/sunday-times/20170312/281840053470410.

${ }^{186}$ Regulation 11(4) of the new Regulations requires an RSDO interview and assessment to take place prior to the issuance of an endorsement.

${ }^{187} \mathrm{RA}$ (as amended) s 22(8)(a).

${ }^{188}$ RA s 22(6). 
shelter and basic necessities by the UNHCR or any other charitable organisation or person'. ${ }^{189}$ Only if they cannot be provided for by such organisations or persons could they be potentially eligible for an endorsement of their right to work. Such endorsement would require them to produce a letter of employment within 14 days of taking up employment. ${ }^{190} \mathrm{It}$ is an offence, punishable by up to R20 000 fine, to employ an asylum-seeker lacking an endorsement. ${ }^{191}$ Finally, the DHA Director-General must revoke the endorsement if an employee is unable to prove that they are employed 'after a period of six months from the date on which such right was endorsed.' ${ }^{192}$

The scheme imposes extremely harsh procedural conditions on employing asylum-seekers (it contains no specific reference to self-employment). Since asylum-seekers are now required to make an application for asylum within five days of entry into the Republic, and since their dependants have to be declared as part of the application, an asylum-seeker has five days to communicate with friends and family and obtain confirmation of their support before they lodge their application. They are denied the right to work whilst the initial assessment takes place. Implicitly, they will not receive an employment endorsement until and unless they can offer proof of a negative - that they cannot receive assistance from UNHCR or other organisations. There could thus be lengthy periods during which asylum-seekers would neither be able to self-sustain nor rely on others (let alone the state) for support, potentially leaving them destitute. Yet, the (modest) Watchenuka ratio - that SA cannot deny asylum-seekers both welfare support and access to gainful employment - remains compelling. Indeed, in its Concluding Observations, CESCR expressed concerns 'that the right of asylum-seekers to work has been denied through Section $22(8)^{\prime} 193$ and called on South Africa to '[e]nsure, to the fullest extent possible, that asylum seekers can support themselves and enjoy the right to work, including by amending [it]'. ${ }^{194}$

The above analysis demonstrates that the RAA 2017 clearly conflicts with previous courts' judgments; but does it breach IRL? Article 17 of the 1951 Convention accords 'refugees lawfully staying ... the most favourable treatment accorded to nationals of a foreign country in the same circumstances, as regards the right to engage in wage-earning employment'. Article 18 accords 'a refugee lawfully in their territory treatment as favourable as possible and, in any event, not less favourable than that accorded to aliens generally in the same circumstances, as regards the right to engage on his own account in agriculture, industry, handicrafts and commerce and to establish commercial and industrial companies'. Hence, IRL draws a temporal distinction between access to self-employment, which applies as soon as a refugee is 'lawfully in' the country, and access to wage-earning employment, which is only required once a refugee is 'lawfully staying'.

It is contended that the relevant interpretive premise should be that of asylum-seekers as 'presumptive refugees' and of an asylum application rendering an asylum-seeker's presence lawful. Even if SA had provided public relief to asylum-seekers, preventing their destitution, IRL would only permit time-limited restrictions on asylum-seekers' access to wage-earning

${ }^{189}$ RA s 22(8)(b).

${ }^{190}$ RA ss 22(8)(c), 22(9). A similar endorsement procedure is envisaged for exercising the right to study at a 'relevant educational institution'.

191 RA s 22(10).

192 RA s 22(11).

${ }^{193}$ ICESCR (note 26 above) at para 25.

${ }^{194}$ Ibid at para 26(c). 
employment - whereas restrictions on self-employment are prima facie suspect. ${ }^{195}$ In Union of Refugee Women (discussed in part II), the majority rejected the argument that the relevant comparators for refugees and asylum-seekers in respect of access to wage-earning employment are favoured non-citizens (permanent residents), ${ }^{196}$ and hence rejected a constitutional claim based on unfair discrimination, even in respect of recognised refugees, let alone asylum-seekers. An IRL-focussed interpretation would have necessitated a different analysis.

The RAA 2017 excludes all asylum-seekers from all forms of self-employment and casual work, irrespective of whether they can self-sustain or rely on others. It also excludes all asylum-seekers who can either self-sustain or can be otherwise supported from wage-earning employment. These exclusions can last indefinitely, given the new regulations remove even the expectation of a timely assessment of asylum applications. Such blanket restrictions are arguably incompatible with IRL.

\section{F Restrictions of political activities}

Regulation 4(2) stipulates that 'no refugee or asylum seeker may participate in any political activity or campaign in furtherance of any political party or political interests in the Republic'. The regulations do not define 'political activity, 'campaign' or indeed 'political interests'.

Whereas IRL is silent on political rights, ${ }^{197}$ IHRL is not: the ICCPR protects the rights of 'everyone' ${ }^{198}$ to 'freedom of expression', of 'peaceful assembly', and to 'freedom of association with others' ${ }^{199}$ Concomitantly, signatories thereto are expected to prohibit 'advocacy of national, racial or religious hatred that constitutes incitement to discrimination, hostility or

${ }^{195}$ Compare Directive 2013/33/EU of the European Parliament and the Council of 26 June 2013 Laying Down Standards for the Reception of Applicants for International Protection (Recast) art 15 ('Employment') which requires EU member states to 'ensure that applicants have access to the labour market no later than 9 months from the date when the application for international protection was lodged if a first instance decision by the competent authority has not been taken and the delay cannot be attributed to the applicant'. It also notes that: 'Access to the labour market shall not be withdrawn during appeals procedures, where an appeal against a negative decision in a regular procedure has suspensive effect, until such time as a negative decision on the appeal is notified'. Importantly, the Directive requires member states to 'ensure that material reception conditions are available to applicants when they make their application for international protection' including 'an adequate standard of living for applicants, which guarantees their subsistence and protects their physical and mental health'. Ibid art 17(2). For discussion, see A Edwards 'Article 17' in Zimmermann (note 123 above) ch 35 at para 34; A Edwards 'Article 18' in Zimmermann (note 123 above) ch 18 at para 10.

Compare GS Goodwin-Gill and J McAdam The Refugee in International Law (3rd Ed, 2007) 526(Suggests that, to meet the 'lawfully staying' threshold, refugees 'must show something more than mere lawful presence', such as 'permanent, indefinite or unrestricted or other residence status, recognition as a refugee, issue of a travel document, or grant of re-entry visa... any of these statuses will raise a strong presumption that the refugee should be lawfully staying in the contracting State, and it would then fall to the State to rebut the presumption by showing, for example, that the refugee was admitted for a limited time and purpose, or that he or she is in fact the responsibility of another State').

${ }^{196}$ Union of Refugee Women (note 103 above) at para 61.

${ }^{197} 1951$ Convention art 5. See also Ziegler Voting Rights of Refugees (note 127 above) ch 2.

${ }^{198}$ HRC General Comment No 31: The Nature of the General Legal Obligation Imposed on State Parties to the Covenant (Adopted on 29th March 2004) (2187th meeting) at para 3 ('the enjoyment of Covenant rights is not limited to citizens of States Parties but must also be available to all individuals, regardless of nationality or statelessness, such as asylum seekers, refugees, migrant workers and other persons, who may find themselves in the territory or subject to the jurisdiction of the State Party').

${ }^{199}$ Articles 19, 21, and 22 of the ICCPR, respectively. 
violence' as well as 'propaganda for war'. ${ }^{200}$ Therefore, in IHRL, asylum-seekers and refugees qua persons within SA's territory and subject to its jurisdiction should enjoy 'political communication' rights there.

In turn, the prohibition on 'subversive activities' in the OAU Convention ${ }^{201}$ and the African Charter on Human and People's Rights ${ }^{202}$ should be interpreted harmoniously with the ICCPR to denote 'the overthrow of the legal, political and social order of the state which another state attempts or achieves by propagating its ideology amongst the political forces of the state which is the target of this undertaking. ${ }^{203}$

The Constitution protects political communication rights of 'everyone', and restrictions are subject to the general (s 36) limitation clause. The enumerated rights are: 'freedom of expression' including 'freedom to receive or impart information or ideas'; $; 04$ the right to 'peacefully and unarmed, to assemble, to demonstrate, to picket and to present petitions' ${ }^{205}$ and the right to 'freedom of association'. ${ }^{206}$ Broadly consistent with the ICCPR, the scope of freedom of expression does not extend to 'propaganda for war', 'incitement of imminent violence', or 'advocacy of hatred that is based on race, ethnicity, gender, or religion, and that constitutes incitement to cause harm'. ${ }^{207}$

Meanwhile, citizens are guaranteed the right to vote in the Republic's elections ${ }^{208}$ as well as the right 'to form a political party', 'to participate in the activities of, or recruit members for, a political party' and 'to campaign for a political party or cause' ${ }^{209}$ There is arguably an overlap between elements of ss 16-18 and of s 19: the 'furtherance of a political interest or cause' as per s 19(1) would often be pursued as part of the individual's freedom to 'impart information or ideas' and may involve assemblies, demonstrations, and petitions, oftentimes exercising freedom of association. Therefore, it is argued that the reference in s 19 to 'citizens' should not be read to restrict non-citizens' political communication rights, but rather to elucidate a holistic account of the self-governance rights that citizens enjoy in the Republic. ${ }^{210}$

SA courts have consistently held that the 'bounds of the constitutional guarantee of free expression' should be interpreted generously, ${ }^{211}$ given that 'individuals in our society need to

${ }^{200}$ Ibid art 20.

${ }^{201}$ Article 3 of the OAU Convention requires 'every refugee' to 'abstain from any subversive activities against any Member State of the OAU' and Signatory States 'to prohibit refugees residing in their respective territories from attacking any State Member of the OAU, by any activity likely to cause tension between Member States, and in particular by use of arms, through the press, or by radio.'

${ }^{202}$ Ibid art 23(2)(a) notes that 'any individual enjoying the right of asylum ... shall not engage in subversive activities against his country of origin or any other State Party to the present Charter; and that (b) their territories shall not be used as bases for subversive or terrorist activities against the people of any other State Party to the present Charter.'

${ }^{203}$ Sharpe (note 6 above) at 82 (referencing E Mbaya 'Political Asylum in the Charter of the OAU: Pretensions and Reality' (1987) 35 Law \& State 63, 74-75).

${ }^{204}$ Constitution s 16(1).

${ }^{205}$ Ibid s 17.

${ }^{206}$ Ibid s 18.

${ }^{207}$ Ibid s 16(2).

${ }^{208}$ Ibid s 19(3)(a).

${ }^{209}$ Ibid ss 19(1)(a) (b), and (c) respectively.

${ }^{210}$ SA courts appear not to have directly addressed this interpretive question.

${ }^{211}$ Laugh It Off Promotions v South African Breweries International (27 May 2005) at para 47. See also Masuku $v$ South African Human Rights Commission [2018] ZASCA 180; 2019 (2) SA 194 (SCA); [2019] 1 All SA 608 
be able to hear, form and express opinions and views freely on a wide range of matters ${ }^{212}$ The Court quashed a provision prohibiting broadcasting of 'material which is indecent or obscene or offensive to public morals or offensive to the religious convictions or feelings of any section of a population or likely to prejudice the safety of the State or the public order or relations between sections of the population', holding that the provision 'self-evidently limited the right to freedom of expression'. ${ }^{213}$ In Garvas, the Court held that 'the right to freedom of assembly ... exists primarily to give a voice to the powerless. This includes groups who do not have 'political or economic power, and other vulnerable persons ... this right will, in many cases, be the only mechanism available to them to express their legitimate concerns' ${ }^{214}$ In Mlungwana, the Court emphasised that the term 'everyone' ... 'must be interpreted to include every person or group of persons'. ${ }^{215}$

Pursuant both to SA's international law obligations and to its Bill of Rights provisions, the rights that reg 4(2) restricts should be enjoyed by everyone in SA, including asylum-seekers and refugees. Elsewhere, ${ }^{216} \mathrm{I}$ argue that, given their political predicament, asylum-seekers and refugees have a particularly strong claim to enjoy 'political communication' rights in their host country. Constitutionally, any restriction on ss 16-18 rights must clear the s 36 limitation clause hurdle - requiring a law of general application that is reasonable and justifiable in an 'open and democratic society based on human dignity, equality, and freedom'. That reg 4(2) singles out asylum-seekers and refugees for adverse treatment (other non-citizens are spared), curtailing their autonomy and undermining their self-respect and dignity, may also give rise to a s 9 unfair discrimination claim. ${ }^{217}$

(SCA); (4 December 2018) at para 16(Refers to the Constitution's 'liberal approach to protection of freedom of expression').

${ }^{212}$ South African National Defence Union v Minister of Defence 1999 (6) BCLR 615 (CC); 1999 (4) SA 469 (CC) at para 7.

213 The Islamic Unity Convention v The Independent Broadcasting Authority [2002] ZACC 3; 2002 (4) SA 294 (CC) (11 April 2002); discussed in Qwelane v South African Human Rights Commission [2019] ZASCA 167; [2020] 1 All SA 325 (SCA); 2020 (2) SA 124 (SCA) (29 November 2019) at para 47.

${ }^{214}$ South African Transport \& Allied Workers Union v Garvas [2012] ZACC 13 (13 June 2002) at para 61.

${ }^{215}$ Mlungwana \& Others $v$ S \& Another [2018] ZACC 45; 2019 (1) SACR 429 (CC) (19 November 2018) at para 43. See also J Duncan 'South Africa's Doctrinal Decline on the Right to Protest: Notification Requirements and the Shift from Fundamental Right to National Security Threat' (2020) 10 Constitutional Court Review 227.

${ }^{216}$ See, generally, R Ziegler 'Freedom of Expression, Assembly and Association and Aliens' Restrictions on their Political Activity (arts. 10, 11, 16, Art. 3 Prot. 1 ECHR)' in D Moya \& G Milios (eds) Aliens Before the European Court of Human Rights: Ensuring Minimum Standards of Human Rights Protection (forthcoming).

${ }^{217}$ Constitution s 9(3): 'the state may not unfairly discriminate directly or indirectly against anyone on one or more grounds including...' For the equality clause tests see Harksen $v$ Lane [1997] ZACC 12; 1998 (1) SA 300 (CC). The list of grounds is non-exhaustive: whereas nationality/citizenship is not included, it can still form the basis of an unfair discrimination claim. See e.g. Khosa v Minister of Social Development [2004] ZACC 11; 2004 (6) SA 505; 2004 (6) BCLR 569 (CC) (4 March 2004) at para 71(Finds exclusions of permanent residence from social welfare scheme to constitute unfair discrimination; the Court noted that acquisition of citizenship is subject to ministerial discretion and is, at least temporarily, a characteristic of personhood not alterable by conscious action and in some cases not alterable except on the basis of unacceptable costs). See also Larby-odam $v$ Minister of the Executive Council for Education (North-West Province) [1997] ZACC 16; 1997 (12) BCLR 1655; 1998 (1) SA 745 (26 November 1997) at para 24(Holds that denying permanent employment opportunities to permanent residents, who 'can be said to have made a conscious commitment to South Africa' constitutes unfair discrimination). For criteria for determining unfair discrimination on an unlisted ground see Hoffman $v$ South African Airways [2000] ZACC 17; 2001 (1) SA 1 (CC). 


\section{PROSPECTIVE CONSTITUTIONAL CHALLENGES}

Part III appraised the adverse effects of the RAA 2017 and its regulations on access to the SA asylum system and to substantive rights. It demonstrated that the impugned legislation, which defies judicial pronouncements, breaches SA's treaty obligations.

This part briefly outlines three potential grounds (to the non-exclusion of others) for mounting constitutional challenges against the RAA 2017. First, the RAA 2017 renders the amended RA internally inconsistent. The amendments brought about by the RAA 2017 breach IRL and IHRL treaty norms, yet the amended RA explicitly requires its interpretation to be consistent with such norms. Hence, by enacting the RAA 2017, Parliament acted irrationally and therefore unlawfully. Second, by restricting access to the asylum system and by denying asylum-seekers substantive rights they currently enjoy, the RAA 2017 violates their constitutional rights to, inter alia, just administrative action; ${ }^{218}$ freedom and security of the person; ${ }^{219}$ freedom of movement and residence; ${ }^{220}$ education; $; 21$ social security; ${ }^{222}$ freedom of expression, demonstration, picket, and petition, and association; ${ }^{223}$ as well as equality ${ }^{224}$ and human dignity. ${ }^{225}$ Third, the RAA 2017 is manifestly retrogressive and may therefore breach the state's s 7(2) constitutional obligations to 'respect, protect, promote and fulfil' the Bill of Rights, interpreted in the light of the non-regression principle.

Section 172(1)(a) of the Constitution stipulates that any court must declare that any law or conduct that is inconsistent with the Constitution is invalid to the extent of its inconsistency. It is hoped that, courts will utilise IRL in their appraisal and declare relevant provisions unconstitutional.

\section{A Legislative inconsistency, rationality, and the principle of legality}

The simultaneous commencement of the RAA 2008 and RAA 2017 modifies both the substantive norms and the interpretive framework for appraisal of the amended RA - pulling in opposite directions. Prior to the RAA 2017, s 6 of the RA instructed SA courts to interpret and give effect thereto 'with due regard' to enumerated instruments to which the Republic has become a party. This necessitated 'serious consideration' both of IRL instruments and of IHRL instruments, especially where it supplements IRL such as in respect of political communication rights. Part II demonstrated that such 'serious consideration' was generally absent hitherto from the Republic's asylum jurisprudence. RAA 2008 replaced $s 6$ with s 1A: courts now must interpret and give effect to the RA 'in a manner consistent with' SA's IRL \& IHRL obligations

${ }^{218}$ Constitution s 33 ('everyone has a right to administrative action that is lawful, reasonable and procedurally fair') and s 3(1) of the Promotion of Administrative Justice Act 2000 ('administrative action which materially and adversely affects the rights or legitimate expectations of any person must be procedurally fair').

${ }^{219}$ Constitution s 12(1) ('everyone has the right to freedom and security of the person, which includes the right (a) not to be deprived of freedom arbitrarily or without just cause').

${ }^{220}$ Ibid s 21(1) ('everyone has the right to freedom of movement').

${ }^{221}$ Ibid s 29(1) ('everyone has the right to (a) a basic education, including adult basic education; (b) further education, which the state, through reasonable measures, must make progressively available and accessible').

${ }^{222}$ Ibid s 27(1)(c) ('everyone has the right to have access to...social security, including, if they are unable to support themselves and their dependants, appropriate social assistance').

${ }^{223}$ Ibid ss 16-18 (text cited in part IIIF).

${ }^{224}$ Ibid s 9 (text cited in part IIIF).

${ }^{225}$ Ibid s 10 (text cited in part IIC). 
— which must therefore become the starting point for appraisal of the amended RA and of its new Regulations.

Yet, as this article has shown, parts of the amended RA cannot be interpreted in a manner that is consistent with IRL. For instance, each of the five additional exclusion clauses entails denial of refugee status to those who qualify as 'refugees' in IRL as defined in s 3 of the RA (refugee status). There is therefore a direct and irreconcilable conflict between $s 4$ of the RA (exclusion) and s 2 (nonrefoulement): a person who meets the $s 3$ refugee definition would be excluded from refugee status pursuant to $s$, but SA authorities would still be enjoined from expelling, extraditing or returning them to any country, given that $s$ applies 'notwithstanding any provision of this Act or any other law to the contrary'. The inevitable outcome is having in SA excluded but non-removable persons whose legal status and rights are in limbo for an indefinite period.

The Court held that 'the exercise of public power by the Executive and other functionaries' must be 'rationally related to the purpose for which the power was given, otherwise they are in effect arbitrary'. ${ }^{226}$ The RAA 2017 renders the RA internally inconsistent, forces the Executive to act irrationally, and is therefore at odds with the constitutional principle of legality. ${ }^{227}$

\section{B Substantive breaches of the Bill of Rights: beyond dignity}

Section 7(2) of the Bill of Rights requires the state to 'respect, protect, promote and fulfil the rights in the Bill of Rights'. As the Glenister judgment postulated, the binding nature of international law obligations on the Republic is most significant when interpreting the obligations under s 7(2). ${ }^{228}$ Implicit in it is the obligation that the steps taken to protect and fulfil constitutional rights must be reasonable. ${ }^{229}$ Section $8(1)$ postulates that the Bill of Rights 'applies to all law, and binds the legislature, the executive, the judiciary and all organs of state'. Parliament is not only obliged to refrain from interfering with fundamental rights but must give effect to them by positive action.

Section 36 of the Bill of Rights stipulates that rights 'may be limited only in terms of law of general application to the extent that the limitation is reasonable and justifiable in an open and democratic society based on human dignity, equality and freedom'. Relatedly, s 39(2) of the Bill of Rights requires courts interpreting any legislation to 'promote the spirit, purport and objects of the Bill of Rights' which are set out in s 7(1) — the democratic values of human dignity, equality and freedom.

The changes to the asylum regime outlined in part III violate substantive rights that asylumseekers enjoy, not just under IRL but also (as part II has shown), pursuant to judicial precedents under the Constitution (invoking the constitutional right to dignity). Whereas the fact that legislation violates IRL does not definitively settle the constitutional question, that is, whether

226 Pharmaceutical Manufacturers Association of South Africa \& Another In re Ex Parte President of the Republic of South Africa [2000] ZACC 1, 2000 (2) SA 674 (CC) at para 79.

${ }^{227}$ New National Party of South Africa v Government of the Republic of South Africa [1999] ZACC 5, 1999 (3) SA 191. In Fedsure, the Court noted that 'the principle of legality is necessarily implicit in the Constitution'. Fedsure Life Assurance Ltd \& Others v Greater Johannesburg Transitional Metropolitan Council [1998] ZACC 17, 1999 (1) SA $374(\mathrm{CC})$ at para 59.

${ }^{228}$ Glenister (note 24 above) at para 189.

${ }^{229} \mathrm{Ibid}$ at para 194. 
the infringement of enumerated rights in the Bill of Rights is reasonable and justifiable, it provides a strong indication of the likelihood of that conclusion being reached in the appraisal.

\section{Non-regression}

The principle of non-regression in international law mandates that, once a country has acted to realise a right, it must at the least maintain the achieved standard of protection henceforth. As Sanya Samtani argues, while the Court in Law Society does not explicitly articulate a principle of non-retrogression (or non-regression) in SA law, it offered an account of what its application looks like in practice. ${ }^{230}$ For instance, in relation to the state's obligation under $s 7(2)$ of the Bill of Rights, '[t] he President's power in terms of section 231(1) is permissibly exercisable only insofar as it is aimed at protecting, promoting, respecting and fulfilling the rights in the Bill of Rights ... [t]here is just no room for deviation, particularly where citizens' existing rights are likely to be undermined or extinguished at any level where they used to be enjoyed.'231 The judgment also holds that 'it is constitutionally impermissible, as long as our Constitution and the Treaty remain unchanged, for the President to align herself with and sign a regressive international agreement that seeks to take away the citizens' right of access to justice at SADC level'. ${ }^{332}$

The RAA 2017 is manifestly retrogressive: it excludes 'refugees' within the meaning of the 1951 and OAU Conventions from receiving refugee status in SA; it renders abandoned asylum claims which under the existing protection regime would be assessed; it facilitates the establishment of APCs, de facto detention centres, whilst removing statutory times for assessing asylum claims; it denies asylum-seekers rights that they currently enjoy in respect of access to employment and education; ${ }^{233}$ it imposes new restrictions on political activities of both asylumseekers and refugees; and it renders refugee status, once granted, subject to additional cessation clauses and, hence, more precarious, and refugee integration significantly less likely. Each of these changes reflects a weakening of SA's commitment to refugee protection. Taken together, they amount to a sea change in its asylum regime.

\section{CONCLUDING REMARKS}

Ratification and domestication of IRL treaties is a necessary but insufficient condition for ensuring effective refugee protection. Judiciaries must be able and willing to appraise legislation and executive actions to determine their compatibility with international standards. In some jurisdictions, the role of international norms in domestic constitutional arrangements is the source of ongoing contention: not so in SA, where an 'international law friendly' constitution

${ }^{230}$ S Samtani 'International Law, Access to Courts and Non-Retrogression: Law Society v President of RSA' (2020)

10 Constitutional Court Review 197.

${ }^{231}$ Law Society (note 17 above) at para 78.

232 Ibid at para 82.

${ }^{233}$ For example, International Commission of Jurists Promoting Non-Citizens' Right to Work in South Africa (April 2020) 43-44 (Recognises the possibility of restrictions and limitations being placed on non-citizens' rights, including the right to work, while affirming clearly that 'any restrictions, including a qualification period, must be proportionate and reasonable' and that 'differential measures taken by the State in relation to economic, social and cultural rights should not be retrogressive'), available at https:/www.icj.org/wp-content/uploads/2020/04/ South-Africa-Non-Citizens-Right-to-Work-Advocacy-Analysis-Brief-2020-ENG-.pdf (referencing CESCR General Comment No. 19: The right to social security (Art. 9 of the Covenant) (4 February 2008) E/C.12/GC/19, available at https://www.refworld.org/docid/47b17b5b39c.html at para 37). 
requires courts to consider international law in interpreting the Bill of Rights and to adopt reasonable interpretations that are compatible with international law whenever they interpret legislation. Enter refugee protection, where the legislation domesticating SA's international obligations has hitherto mandated interpretive 'due regard' to IRL and international human rights instruments.

In their jurisprudence, courts have generally resisted the Executive's repeated efforts to frustrate asylum-seekers' rights, finding them to be against the spirit and the letter of the RA. Their judgments acknowledge that, without effective access to rights and absent welfare support, asylum-seekers will be destitute, which would violate their constitutional right to human dignity. Over the past two decades, courts have attempted to bridge the gap between designation of persons as 'illegal foreigners' under the IA and the protection from refoulement that they enjoy under the RA. Yet, I have shown in this article that SA courts have under-utilised IRL norms, rarely articulating an IRL rationale for their judgments. Crucially, they have not challenged the normatively flawed core premise of (many) Executive policies: namely that, in its eyes, despite the express language of s 1 (v) of the RA, refugee status is constitutive of rights, rather than declaratory.

The RAA 2017 forces a direct clash between the promise of the RA and its (amended) legal reality. Coupled with the RAA 2008 induced requirement, pursuant to s 1A, to interpret and give effect to the RA 'in a manner consistent with' IRL, courts will soon be called upon to pronounce on overt breaches of IRL in primary and secondary legislation that cannot be reconciled with the SA's international obligations. The time is ripe. 